\title{
土木計画における 応用空間統計学の可能性
}

\author{
堤 盛人 $1 \cdot$ 瀬谷 創 2 \\ 1正会員 筑波大学准教授 システム情報系（†305-8573 茨城県つくば市天王台 1-1-1） \\ E-mail: tsutsumi@sk.tsukuba.ac.jp \\ 2学生会員 国立環境研究所地球環境研究センター（テ305-8506つくば市小野川 16-2） \\ E-mail: seya.hajime@nies.go.jp
}

\begin{abstract}
自然科学への応用から生まれた空間統計学 (狭義には地球統計学) と地域科学・地理学における計量革命 から派生した空間計量経済学は, これまで独自の発展を経てきたが, 近年, 社会経済デー夕を用いた研究に 後者だけでなく前者も応用されることが増えるなど，相互の交流が盛んになってきている，本稿では，二 つの学問の土木計画学分野での実用化と応用の促進に寄与することを目的に, これらの分野に拈ける実証 研究とそこでの課題について最新の研究動向も踏まえながら整理を行い, 土木計画に拈ける「応用空間統 計学 (applied spatial statistics)」の可能性について論じるものである.
\end{abstract}

Key Words: spatial data, applied spatial statistics, spatial econometrics, geostatistics, empirical application

\section{1. はじめに}

地理空間情報に関するデータは，既に我々の日常 の至る所で利活用されている。本稿において地理空 間情報とは, 2007 年に成立した地理空間情報活用推 進基本法に基づき,『空間上の特定の地点又は区域の 位置を示す情報である「位置情報」又は/ 及びそれに 関連付けられた情報』を意味することとし，以下，地 理空間情報に関するデー夕を簡単に空間データと称 することとする，空間データに関する分析は，広く 社会科学全般において重要な位置を占めるように なっている ${ }^{1)}$ 。これには, 空間デー夕の入手が従来 と比べて格段に容易になっていることが大きい，我 が国では，例えば，国土数值情報において，地価公 示, 土地利用, 交通等, 多種多様な空間データが提供 されている，最近では，プローブカー等の新たなの 空間デー夕も取得されつつある。空間データは, 非 常に多くの分野に関連するため, そのハンドリング や分析モデリングについて, 現在までに様々な分野 で膨大な知見が蓄積されてきた。

まず，自然科学の分野では，鉱山学における実務 に端を発し, 地球統計学 (geostatistics) と呼ばれる空 間デー夕を空間上での連続量として扱う学問分野が
成立した ${ }^{2), 3)}$ 。その後, 地球統計学は, 空間統計学 (spatial statistics) の主要な一分野として位置づけら れ，学問として洗練の域に達しつつある4)(ただし, 今日でも, 地球統計学という名称は標準的に使われ ている） ${ }^{5)}$. 一方, 地理学の分野に目を移すと, 統計 学的な観点から見た時の空間データの本質は, 距離 が近い程事物の性質が似る（あるいは異なる）とい う「空間的自己相関 (spatial autocorrelation)」と, 地域 の固有性（異質性）（spatial heterogeneity）にあると広 く認識されている。距離が近い事物がより強く影響 しあうという Tobler (1970) ${ }^{6)}$ の地理学の第一法則 (first law of geography) として知られる性質は, 計量 地理学に打ける最も基礎的かつ重要な問題の一つで あることが 60 年代から指摘され7) 10), 現在地理学 を背景とする研究者のテキストでは, 空間的自己相 関・異質性を考慮したモデリングは, 空間データ分 析 (spatial data analysis) の一部として捉えられてい $3^{11), 12)}$ ．他方，特に行政界等の離散的なゾーンにお いて収集された情報を扱うことが多い地域科学の分 野では, 計量地理学の流れを汲みながら, Anselin (1988） ${ }^{13)}$ や LeSage and Pace（2009）14)に代表される 空間計量経済学 (spatial econometrics) が発展した。 Spatial econometrics という呼称は, 70 年代初頭にべ 
ルギーの経済学者である Jean Paelinck が用い始めた とされる ${ }^{15)}$ 。ちょうど, 経済学において, 長い間空 間概念が捨象されてきたように年), 計量経済学の興 味の中心は「時間」(時系列) であった。しかしなが ら近年，空間計量経済学は理論・実証面ともに大き く発展し, 数多くの国際誌で特集号が組まれるなど, 今や計量経済学の重要なテーマの一つとなってい る ${ }^{17)}$ ，土木計画学に执いても，佐々木 $(1984)^{18)}$ 田中（1984） ${ }^{19)}$ 等，比較的早い時期から空間デー夕 に内在する特質とこれに対する統計学的な対処の必 要性が認識されていた。例えば奥村ら (1989) ${ }^{20)}$ は, 筆者らの知る限り, 連立方程式型の地域モデルのパ ラメータ推定に, 空間計量経済学の手法を応用した 最初の研究の一つである。 その後現在までに, 空間 計量経済モデルを応用した様々な重要かつ興味深い 研究が行われている 21 -25). とりわけ, 塚井 $(2005)^{26)}$ は空間計量経済学に関する貴重なレビューである。

ここで, 学問分野の呼称について, 少し議論して おきたい。本来,「空間統計学」という言葉は, 空間 デー夕を統計学的に扱う学問, としての意味を持っ ても良さそうである。事実, 塚井 (2005） ${ }^{26)}$ のレ ビューは，そのような意図で「空間統計モデルのフ ロンテイア」という呼称を用いていると推察される。 筆者らは, 空間統計学と空間計量経済学を合わせて 「広義の空間統計学」, 特に前者のみを指して「狭義 の空間統計学」という呼ぶことも多い. しかしなが ら近年では, 連続な確率場を想定し連続データのモ デリングを扱う学問体系を指して空間統計学・地球 統計学と呼び, 離散データのモデリングを扱う学問 体系を空間計量経済学と称する区別が一般的である ように思われる。これに関して Cressie (1993， p. 443) 4)は, “From a statistician's perspective, the distinction is not particularly helpful”と述べている. 実 際，両者に扔けるモデリング技法には共通点が多く, 空間統計学と空間計量経済学を分類することにさほ ど利点はないとも考えられる。そればかりかこのよ うな区別により, Anselin (1986) ${ }^{27)}$ が, “each approach tends to be rather self-contained, with little cross-reference shown in published articles”と述べたよ うな弊害が生じ, 同一のモデルに対し二つの分野で 異なる呼称が用いられるといった混乱によるある種 の相互参入障壁が存在しているのも事実である。一 方で, 徐々にその参入障壁が低くなりつつあるよう な状況も生まれている。実際，2011年に開催された Spatial Econometrics Association の第 5 回 World Conferenceで, 冒頭に招待講演を行ったのは, 空間 統計学の第一人者である Noel Cressie 教授であった. このような問題意識のもと, 本稿の表題では, 空間
統計学・計量地理学・空間計量経済学の垣根を越え て, 応用指向型の空間デー夕分析を扱う学問分野の 総称という意味を达めて,「応用空間統計学」という 呼称を用いることとした。

堤・瀬谷 (2012) ${ }^{28)}$ では, 両分野の基礎的なモデリ ング技法について, 最新の研究成果を踏まえながら 横断的なレビューを行った。しかしながらそこで は, 紙面の都合上, 実証研究に関するレビューを割 愛せざるを得なかった，そこで本稿では，両分野の 手法を用いた実証研究に関するレビューを行い, 土 木計画学分野での応用空間統計学のさらなる実用化 と応用の促進に資すること目的とするものである。 以下第二章では, まず, 空間データの特質について 簡単に説明・考察する。次に第三章では, 応用空間 統計学の基本的なモデリング技法（地球統計モデル と空間計量経済モデル）を概観する。なお，第二章・ 第三章の内容の一部は, 堤・瀬谷 $(2012)^{28)}$ と重複す るが, これは読者の利便性と論文としての一貫性を 担保するためでありご容赦願いたい。 さらに，第四 章で地球統計学・空間計量経済学に関連する実証研 究についてレビューを行い, 残されている課題につ いて論じる. 最後に, 第五章において, 今後の土木 計画に扮ける実証・応用研究の展望について論じる。

\section{2. 空間データの特質 : 空間的自己相関と空間的 異質性}

\section{（1）空間データの類型}

空間統計学の代表的なテキストであるCressie $(1993)^{4)}$, Banerjee et al. (2004) ${ }^{29)}$, Schabenberger and Gotway（2005） ${ }^{30)}$ では, 空間デー夕を, [1]地球 統計デー夕, [2] 地域/格子デー夕, [3] 点過程デー夕 の 3 種類に分類している(ただし, 用いている名称 はそれぞれ異なる)。 今, $\boldsymbol{s} \in \Re^{d}$ が, 次元 $d$ (通常 $d=$ 2または3）のユークリッド空間におけるデータの位 置であるとし, $\boldsymbol{Y}(\boldsymbol{s})$ は, 空間的な位置ににおけるラン ダムな量 (多変量) であるとしよう。ここで, $\boldsymbol{s か ゙ イ ~}$ ンデックス集合内を動くとき， $\{\boldsymbol{Y}(\boldsymbol{s}): \boldsymbol{s} \in D\}$ は，空 間過程, あるいは確率場と呼ばれる。また, Cressie and Wikle $\left(2011\right.$, p. 18) ${ }^{31)}$ 同様, 時間軸を導入した時 空間過程は, $t$ が $T \subset \Re$ 内を連続的に動くとき, $\{\boldsymbol{Y}(\boldsymbol{s} ; t): \boldsymbol{s} \in D, t \in T\}$, 離 散 的に動くとき, $\left\{\boldsymbol{Y}_{t}(\boldsymbol{s}): \boldsymbol{s} \in D, t \in T\right\}$ と表されるとする。 [1] の地球統 計デー夕は, 領域 $D$ が連続 (continuous) で固定され た（fixed）集合である場合の空間データである。す なわち, $\boldsymbol{Y}(\boldsymbol{s})$ が領域 $D$ 内のいたるところで観測可能 
であり，例えば，標高，気温デー夕等がこれに該当す る. 土木分野に扔いても, 地盤沈下量・地震動・降雨 量・地下水位の推計に対して地球統計学の手法を用 いた研究が行われてきた ${ }^{32) ~ 36) . ~}$. 地球統計学のモデ ルは, 現在でも自然科学の分野での適用が中心であ るが, 社会科学の分野での適用例も着実に増加して いる ${ }^{37), 38)}$. 一方, [2]の地域デー夕は, 領域 $D$ が固 定されており，いくつかの領域から構成される場合 の空間データである。ここで, $\boldsymbol{Y}(\boldsymbol{s})$ は, 離散的な領 域でのみ観測可能である。例えば, ゾーンに集計さ れた社会経済データや，ピクセルを単位とした衛星 リモートセンシング画像デー夕等がこれに該当す る. [3]の点過程データとは, $D$ 自体がランダムな場 合の空間データであり，イベントが生起した位置を 示す，例えば，犯罪の分布等が考えられよう。我が 国では, カーネル密度推定法を用いた犯罪分析につ いて既に多くの実証研究が存在する ${ }^{39)}$ 。また, 畠ら ${ }^{(2006)}{ }^{40)}$ は, 井戸の配置計画のために空間点過程ア プローチを用いている.

なお, 筆者らは[3]の点過程データの分析に関して の経験を有しないため, レビューの対象から外すこ とをご容赦いただきたい。点過程デー夕の分析につ いては, 間瀬ら (1992) ${ }^{41)}$, Diggle $(2003)^{42)}$, 古谷 (2011） ${ }^{43}$ 等を参照されたい。 また，本論文では特に 断らない限り, 一変量に関する空間過程 $Y(\boldsymbol{s})$ を想定 する. 多変量モデルについては, Wackernagel (1998) ${ }^{5)}$ に詳しく, 実証研究としては歳森 $(2002)^{44)}$ 等がある。以下では，一般的な呼び方に倣い，連続 な確率場を想定した地球統計デー夕を扱うモデルを 「地球統計モデル」, 離散的な確率場を想定した地域 デー夕を扱うモデルを「空間計量経済モデル」と呼 ぶこととする。無論, 分野名の定義はここでは重要 ではなく, 前述の数学的な意味での空間の捉え方の 違いに本質的な意味があると理解されたい.

\section{（2）空間的自己相関と空間的異質性}

空間デー夕分析においては, 地域という空間的な 広がりを持った対象を扱うことに起因する特有の問 題, 具体的には空間的自己相関と空間的異質性から なる空間的影響（spatial effects）を考慮する必要があ る ${ }^{13)}$. 空間的自己相関は, 距離の近いデー夕が似た ような傾向を示すという「正の空間的自己相関」と, 距離の近いデータが非常に異なる值を示し, いわゆ るチェッカーボードパターンが形成される「負の空 間的自己相関」に大別される。空間的自己相関は, 次のような積率条件で表される15).

$$
\operatorname{Cov}\left(y_{i}, y_{j}\right)=E\left(y_{i} y_{j}\right)-E\left(y_{i}\right) \cdot E\left(y_{j}\right) \neq 0, \quad \forall i \neq j
$$

ここで, $y_{i}$ と $y_{j}$ はそれぞれ地点 $i, j$ における確率変数 $Y\left(s_{i}\right), Y\left(s_{j}\right)$ の実現值を示す。一方, 空間的異質性 とは, 単に不均一分散やモデル構造の不安定性 (structural instability) のことを指し，通常の計量経済 学の手法で対処可能な場合も多い45). しかしなが ら, 異質性が空間的な構造を持つ場合は, 空間的な 可変パラメータモデル等の専用の対処法が必要とな $ろ^{46)}$.

\section{3. 応用空間統計学の概観}

\section{（1）地球統計モデル}

\section{a）地球統計モデリングの基本的な考え方}

地球統計デー夕は $D$ を連続的な点の集合とみなす のに対し，地域データでは多くの場合 $D$ を離散的な 領域の集合とみなす。これに対応して，両データで 用いられるモデリング技法も異なる。地球統計モデ ルでは, 通常トレンドを除いた誤差項の空間過程が, 弱定常性, すなわち $\operatorname{Cov}[u(\boldsymbol{s}), u(\boldsymbol{s}+\boldsymbol{h})]=C(\boldsymbol{h})$ (ただ し $\left.\boldsymbol{h} \in \Re^{d}\right)$ を満たすとする。ここで, $C(\boldsymbol{h})$ は, 共分散 関数あるいはコバリオグラムと呼ばれる関数であ り, これは共分散をhのみの関数として表したもの に他ならない. $C(\boldsymbol{h})$ が長さ\|h\|のみに依存する（す なわち方位には依存しない）とき, 空間過程は等方 的（isotropic）であるといわれる。

b）基本的な地球統計モデル

地球統計デー夕の代表的モデルである空間過程モ デル (spatial process model（SPM) ) は, 回帰モデルに おける誤差項べクトル $\boldsymbol{u}$ が従う分散共分散行列 $\Sigma$ を 共分散関数を用いて直接構造化するという点に特徵 がある. すなわち, SPMでは, 分散共分散行列の構 造化のために, 通常誤差項が従う分布が弱定常であ るという仮定を㧈く，パラメー夕推定においては, 共分散関数と逆の関係にあり, 值の非類似度の測度 と解釈されるバリオグラム: $E[u(\boldsymbol{s}+\boldsymbol{h})-u(\boldsymbol{s})]^{2}=\operatorname{Var}[u(\boldsymbol{s}+\boldsymbol{h})-u(\boldsymbol{s})]=2 \gamma(\boldsymbol{h})$ を 用いることが多い．共分散関数（バリオグラム）の 特徴を示すパラメータは, ナゲット (nugget, $\left.\tau^{2}\right) \cdot レ$ ンジ $($ range,$\phi)$ ・パーシャルシル (partial-sill, $\left.\sigma^{2}\right)$ の 3 つがある. 共分散関数の関数形は多数提案されて おり, 実証研究においては, spherical 型, exponential 型, Matérn 型等が用いられることが多い. ナゲット は, 観測誤差と扱うか, 観測地点のよりも短いとこ ろでの局所的変動と扱うかで, 処理方法が異なるの 
で注意が必要である ${ }^{30)}$. 今, 共分散関数のパラメー タベクトルを $\xi=\left(\sigma^{2}, \tau^{2}, \varphi\right)^{\prime}$ とすると, SPM は次式で与 えられる。

$$
\begin{aligned}
& \boldsymbol{Y}=\boldsymbol{X} \beta+\boldsymbol{u} \\
& \boldsymbol{u} \sim(\mathbf{0}, \Sigma(\xi))
\end{aligned}
$$

ここで, $\boldsymbol{Y}$ は $Y_{i}$ からなる $N \times 1$ の従属変数べクトル, $\boldsymbol{X}$ は $N \times K$ の説明変数行列（定数項を含む）, $\beta$ は $K \times 1$ の回帰係数べクトル，0は 0 からなる $N \times 1$ ベク トルであり, 分散共分散行列 $\Sigma=\sigma^{2} \boldsymbol{H}(\varphi)+\tau^{2} \boldsymbol{I}$ の $i, j$ 成分 $\Sigma_{i j}$ は, 共分散関数で直接定式化される（Iは $N \times N$ の単位行列, $\boldsymbol{H}$ は $N \times N$ の相関行列). パラ メー夕推定法等の詳細については, 堤・瀬谷 (2012) ${ }^{28)}$ を参照されたい。

さて, SPM は, 空間過程に弱定常性を仮定するた め, 自然な形で任意地点に扔ける確率変数の予測 (内 挿）に用いることができる。この内挿は，空間内挿 技術の発展に貢献した南アフリカの鉱山技師 D. G. Krigeにちなんで, クリギング (kriging) と呼ばれ る ${ }^{47)}$ 。 クリギングによる予測量は, 予測誤差分散最 小化により合理的に求められ, 最良線形不偏予測量 を与える。ここでクリギングは，トレンド成分 $\boldsymbol{X}$ が 無い場合 ordinary kriging (OK)，トレンド成分がある 場合 universal kriging (UK) と呼ばれることが多いが, 名称は必ずしも統一されているわけではない. UK による地点 $\boldsymbol{s}_{0} に$ に打る確率変数の予測量とクリギン グ分散と呼ばれる予測誤差の分散は, 次式により与 えられる。

$$
\widehat{Y}\left(\boldsymbol{s}_{0}\right)=\boldsymbol{x}_{0}^{\prime} \widehat{\beta}+\widehat{\boldsymbol{c}}^{\prime} \widehat{\Sigma}^{-1}(\boldsymbol{Y}-\boldsymbol{X} \widehat{\beta})
$$

$$
\hat{\sigma}^{2}\left(\boldsymbol{s}_{0}\right)=\widehat{\Sigma}(0)-\hat{\boldsymbol{c}}^{\prime} \bar{\Sigma}^{-1} \boldsymbol{c}+\left(\boldsymbol{x}_{0}^{\prime}-X^{\prime} \hat{\Sigma}^{-1} \boldsymbol{c}\right)^{\prime}\left(X^{\prime} \widehat{\Sigma}^{-1} X\right)^{-1}\left(\boldsymbol{x}_{0}^{\prime}-X^{\prime} \hat{\Sigma}^{-1} \hat{\boldsymbol{c}}\right)
$$

ここで, $x_{0}$ は予測地点における説明变数ベクトル, $\boldsymbol{c}$ は, 観測地点と予測地点の確率変数間の共分散べク トルである。

\section{（2）空間計量経済モデル}

\section{a）空間計量経済モデリングの基本的な考え方}

観測值が $N$ 個のクロスセクションデータにおいて は, $N \times N$ 分散共分散行列をデー夕から直接求め ることはできない，地球統計学のモデル（SPM）で は, 共分散関数, 又はバリオグラムを用いて, 分散共 分散行列を直接構造化することでこの問題の解決を 図っている。一方で, 空間計量経済モデルでは, 空 間過程を構造化することで, この問題に対処するこ
とを試みる。後述する空間重み行列 $\boldsymbol{W}$ は, 観測值 ${ }^{14)}$ またはその背後の空間過程 ${ }^{31)}$ を構造化するための便 利で簡潔な道具である ${ }^{14)}$ 。すなわち, 空間計量経済 モデルは，Wを用いることにより，時系列の計量経 済モデルの知見を援用したモデル化を可能とした点 に大きな特徵がある。しかしながら，時間は過去か ら未来へ一方向に影響が及ぶのに対し, 空間では双 方向，すなわち相互に影響が及ぶという空間相互作 用がある点で本質的な違いがあり，この影響がパラ メー夕推定を難しくする ${ }^{48)}$.

\section{b） 代表的な空間計量経済モデル}

空間計量経済学に扔ける代表的なモデルは, 空間 ラグモデル（spatial lag model（SLM））と空間誤差モ デル (spatial error model (SEM)) である. SLMは, 次式のように定式化される.

$$
\boldsymbol{Y}=\rho \boldsymbol{W} \boldsymbol{Y}+\boldsymbol{X} \beta+\varepsilon
$$

ここで, $\rho$ は空間パラメータ, $\varepsilon$ は $N \times 1$ の平均 0 の i. i. d. (independently and identically distributed) 誤差の ベクトルである。 $\boldsymbol{W}$ は, $N \times N$ の空間重み行列であ $\eta, \boldsymbol{s}_{i}$ と依存関係にある近隣集合を $S_{i} \subset D$ と定義し たとき， $\boldsymbol{s}_{i}$ と $\boldsymbol{s}_{j} \in S_{i}$ の関係を記述するものである。地 点（地域） $\boldsymbol{s}_{i}, \boldsymbol{s}_{j}$ に打ける確率変数に何らかの依存関 係があれば, $\boldsymbol{W}$ の $i, j$ 要素 $w_{i j}$ は, $w_{i j} \neq 0$ とされる。慣 習的に，自身からの影響は存在しない，すなわち対 角行列の要素は 0 とされる。 さらに, それぞれの行 $i$ に対して, 行和が 1 となるように行基準化されるこ とが多い. 式 (5) は, 時系列モデルとの対比で, 空 間自己回帰モデル（spatial autoregressive model）と呼 ばれることも多く ${ }^{14)}$, 呼称は統一されてはいない ${ }^{49)}$. SLM は, 空間的・社会的な相互作用の結果起こる均 衡をモデル化するものである ${ }^{50)}$ 。一時点のクロスセ クションデータでは，実際に生じた空間的・社会的 な相互作用は観測できないが, 相互作用の結果至っ た均衡に打ける相関構造をモデル化することは可能 である，SLMにおいて，従属変数の空間ラグ $\boldsymbol{W} \boldsymbol{Y}$ は 誤差項と相関を持つため, 内生变数として扱わなけ ればならない, 従って, 内生性を考慮しない OLSに よる空間パラメータの推定量は一致性を持たず, $\rho=0$ でなければ不偏性も満足しない13).

一方, SEM は, 誤差項同士の空間的な自己相関関 係をモデル化しようとするものであり，経済理論的 理由よりは, 測定誤差が空間的な意味で系統的に存 在する等の, デー夕の問題を処理する目的で用いら れることが多い51)。Dubin (1988) ${ }^{52)}$ は, 残差の空間 的自己相関が生じる理由について, 定量化が難しい （不可能な）影響の存在を指摘している。代表的な 
SEM は, 空間自己回帰型（SAR）の誤差項を持つ, 次 式のモデル（以下，SAR 誤差モデル）である.

$$
\begin{gathered}
\boldsymbol{Y}=\boldsymbol{X} \beta+\boldsymbol{u} \\
\boldsymbol{u}=\lambda \boldsymbol{W} \boldsymbol{u}+\varepsilon
\end{gathered}
$$

ここで入は空間パラメータである，既往研究では，式 （6）自体を指して（狭義の）SEM と呼ばれることも 多い. しかしながら誤差項の空間過程のモデル化手 法は他にも多数存在するため, 厳密には区別するこ とが望ましい. SAR 誤差以外の SEM, 及びパラメー 夕推定方法については堤・瀬谷（2012） 28)を参照さ れたい.

空間計量経済学の分野の代表的な空間的異質性の 考慮法は, 回帰係数を地点・地域毎に与える地理的 加重回帰モデル (geographically weighed regression (GWR) )である46)。また, Islam and Asami (2011） ${ }^{53)}$ は，スイッチング回帰モデルを用いて，SLMの空間 的な構造変化を考慮している。

c）より一般的な空間計量経済モデル

今，SLM，SEM を特殊系として含む，次のような 一般的なモデルを考えよう（Manski モデル） ${ }^{54)}$.

$$
\begin{gathered}
\boldsymbol{Y}=\rho \boldsymbol{W} \boldsymbol{Y}+\boldsymbol{X} \beta+\boldsymbol{W} \boldsymbol{X} \gamma+\boldsymbol{u} \\
\boldsymbol{u}=\lambda \boldsymbol{W} \boldsymbol{u}+\varepsilon
\end{gathered}
$$

これらのすべての項を入れた場合，パラメータの 識別はできない. 式（7）から $\boldsymbol{W} \boldsymbol{X}$ の項を落とした, SLM と SAR 誤差モデルの組み合わせは, 一般化空 間 (SAC) (general spatial autoregressive model with a correlated error term に由来）モデルと呼ばれる。一方 で, $\lambda=0$ として $\boldsymbol{W} \boldsymbol{u}$ の項を落とし, 通常の説明変数に 加えて従属変数と説明変数の空間ラグを導入したモ デルは, 空間ダービンモデル (spatial Durbin model (SDM) ) と呼ばれる.

LeSage and Pace (2009) ${ }^{14)}$ は, クロスセクション分 析において空間計量経済モデルを用いる動機を，

(i) A time dependence motivation

(ii) An omitted variable motivation

(iii) A spatial heterogeneity motivation

(iv) An externatlities-based motivation

(v) A model uncertainty motivation

の 5 つに整理し，特にSDM の有用性を指摘してい る。ここで, (i) は, 例えば自治体 $i か ゙, ~ t-1$ 期に近隣 自治体 $j$ がある税の税率を上昇させたという行動を 観察した後, $t$ 期において, 同一の税の税率を上昇さ
せる行動をとったとすると, $t$ 期のクロスセクション データでは, 税率の空間的なクラスターが観察され るといった状況を示す．（ii）は，除外変数が空間的 な自己相関を持ち, かつ導入されている変数 $\boldsymbol{X}$ と相 関する場合， $\beta$ はバイアスを持つため, この影響を明 示的に取り除く動機である。（iii）は，パネルデータ で標準的に導入される地域固有効果の代理変数とし て, 空間的に相関する誤差項を導入するものである. (iv) は, ある地域 $i$ の出力 $Y_{i}$ が, 同地域 $i$ における属 性だけでなく, 近隣地域の属性からも影響を受ける 「空間的スピルオーバー」をモデル化する動機であ る。（v）は，モデルの不確実性の観点から， SLM, SEM より一般的なモデルであるSDM の使用を薦め るものである、しかしながら筆者らの経験上，SDM のような説明変数の空間ラグを含むモデルは, 多重 共線性の問題に悩まされることが多く, 適切な変数 選択抜きには，実証研究では必ずしも使いやすいと は言えないのも事実である55).

d）空間ラグを用いた場合の回帰係数の意味解釈

空間計量経済モデルにおいては，(特に従属変数 の）空間ラグの導入により, 回帰係数の推定值の解 釈に注意を要する。すなわち, 通常の回帰モデルと, SLM や SDM の回帰係数推定值を直接比較すること はできない.ここでこの点について SDM を例に整 理しておきたい， $m$ 番目の属性が変化したとき， $\boldsymbol{Y}$ の限界的な変化は,

$$
\begin{gathered}
{\left[\frac{\partial \boldsymbol{Y}}{\partial x_{1 m}} \cdots \frac{\partial \boldsymbol{Y}}{\partial x_{N m}}\right]=\left[\begin{array}{lll}
\frac{\partial Y_{1}}{\partial x_{1 m}} & \cdots & \frac{\partial Y_{1}}{\partial x_{N m}} \\
\vdots & \ddots & \vdots \\
\frac{\partial Y_{N}}{\partial x_{1 m}} & \cdots & \frac{\partial Y_{N}}{\partial x_{N m}}
\end{array}\right]} \\
=[\boldsymbol{I}-\rho \boldsymbol{W}]^{-1}\left[\begin{array}{llll}
\beta_{m} & w_{12} \gamma_{m} & \cdots & w_{1 N} \gamma_{m} \\
w_{21} \gamma_{m} & \beta_{m} & \cdots & w_{2 N} \gamma_{m} \\
\vdots & \vdots & \ddots & \vdots \\
w_{N 1} \gamma_{m} & w_{N 2} \gamma_{m} & \cdots & \beta_{m}
\end{array}\right]
\end{gathered}
$$

によって得られる。ここで, $[\boldsymbol{I}-\rho \boldsymbol{W}]^{-1}$ は, 空間乗 数 (spatial multiplier) と呼ばれる. Elhorst (2010) ${ }^{54)}$ は，SDMに打ける限界便益の解釈を，次のような簡 単な例を用いて示している. 今, 直線状に並んだ 1 , 2, 3 という 3 つの地域を想定しょう。地域が隣接し ているとき依存関係があるとすれば, 次の空間重み 行列 (隣接行列) が得られる。

$$
\boldsymbol{W}=\left[\begin{array}{lll}
0 & 1 & 0 \\
w_{21} & 0 & w_{23} \\
0 & 1 & 0
\end{array}\right]
$$

ここで, 次式が成り立つ。 


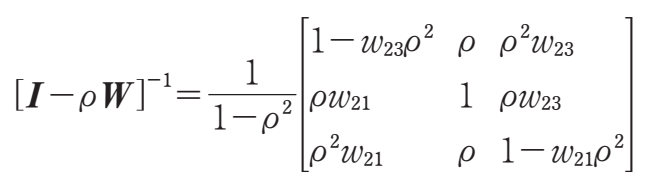

式（9）と, 式（10）より，次式が得られる.

$$
\begin{aligned}
& {\left[\frac{\partial \boldsymbol{Y}}{\partial x_{1 m}} \frac{\partial \boldsymbol{Y}}{\partial x_{2 m}} \frac{\partial \boldsymbol{Y}}{\partial x_{3 m}}\right]=}
\end{aligned}
$$

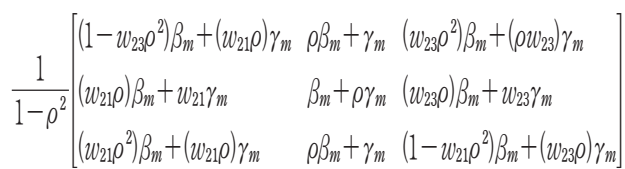

この式から，SDMに打ける限界便益について，次の 3 つの特徵が分かる。1 点目は，ある地域における説 明変数の変化が, 自地域だけでなく, 近隣地域の従 属変数にも影響を与える点である。ここで, 自地域 への影響は直接的影響 (direct effect (DE)), 他地域 への影響は間接的影響（indirect effect（IDE））と呼ば れる。言うまでもなく, DE は, 式 (11) 右辺の対角 項, IDEは, 非対角項である。 2 点目は, 式 (11) か ら示唆されるように, DEと, IDEは, 地域によって 異なるということである. LeSage and Pace (2009) ${ }^{14)}$ は, DE と IDEの要約統計量を提案しており, Seya et al. (2011） ${ }^{56)}$ は，我が国における所得格差分析に適 用している. 3 点目は， $\gamma_{k} \neq 0$ の IDE が局所的な影響 である一方で, $\rho \neq 0$ IDE は大域的な影響であると いう点である.SDMの実証研究への適用は,

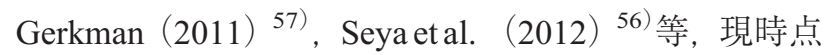
では非常に限られており, 研究の蓄積が期待される。

\section{e）空間重み行列に関わる課題}

空間計量経済モデルは $\boldsymbol{W}$ 用いたモデル化を行う ため,このWの特定化に結果が依存するという点に 本質的な課題がある。しかしながら，現状では正し い空間重み行列の選択に関するガイドラインがほと んど存在しないと指摘されている58). Stakhovych and Bijmolt (2008) ${ }^{59)}$ は，重み行列の与え方を，(a) 完全に外生とする，(b) デー夕から決定する，(c) 推 定するという3つに分類している。（a）は，地域の 境界が接しているか否か (隣接行列) や, 距離の逆数 等で与える典型的な方法である。（b）には, 社会ネッ トワークや，経済的な距離などで与えるアプロー チ60),61) や， ローカル統計量 $G$ に基づき構築する手 法 ${ }^{62)}$ が該当する。（c）としては，Wのエントロピー 最大化法による推定が挙げられる ${ }^{63)}$. いずれにし ろ, 空間計量経済モデルにおいて，Wの特定化は極 めて重要なステップであり, シミュレーション研究 の蓄積と実デー夕を用いた検証の両方が求められて いる.

\section{f） 空間フィルタリング・アプローチ}

$\boldsymbol{W}$ を用いない興味深いアプローチの一つとして,
Griffith らは, その一連の研究で, (変換した) 隣接行 列の固有べクトル $\left(\boldsymbol{e}_{1}, \ldots, \boldsymbol{e}_{N}\right)$ を説明変数として導入す ることで, 空間的自己相関を考慮しつつパラメータ の OLS 推定を可能とする空間フィルタリング（spatial filtering $(\mathrm{SF}))$ アプローチを提案している ${ }^{64)}$. 通 常の空間計量経済モデルが, 空間的自己相関を構造 化するという方法をとる一方で，SF は，空間的自己 相関を除去した上で, 通常の回帰モデルを用いると いう方法をとる，今，次の二つの射影行列を考えよ う.

$$
\begin{gathered}
\boldsymbol{M}_{(1)} \equiv \boldsymbol{I}-\mathbf{1}\left(\mathbf{1}^{\prime} \mathbf{1}\right)^{-1} \mathbf{1}^{\prime} \\
\boldsymbol{M}_{(D)} \equiv \boldsymbol{I}-\boldsymbol{X}\left(\boldsymbol{X}^{\prime} \boldsymbol{X}\right)^{-1} \boldsymbol{X}^{\prime}
\end{gathered}
$$

ここで，1は，1 を要素とする $N \times 1$ ベクトルである. 次式から得られる固有べクトル $\left(\boldsymbol{e}_{1}, \ldots, \boldsymbol{e}_{N}\right)_{S E M}$

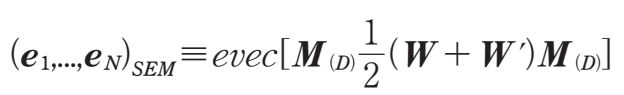

は，Wが隣接行列のとき説明变数に直交する。一方 で, 次式 (14) から得られる固有べクトル $\left(\boldsymbol{e}_{1}, \ldots, \boldsymbol{e}_{N}\right)_{S L M}$

$$
\left(\boldsymbol{e}_{\left.1, \ldots, \boldsymbol{e}_{N}\right)_{S L M}} \equiv \operatorname{evec}\left[\boldsymbol{M}_{(1)} \frac{1}{2}\left(\boldsymbol{W}+\boldsymbol{W}^{\prime}\right) \boldsymbol{M}_{(1)}\right]\right.
$$

は, 説明変数と相関を持つ可能性がある. 今, $\boldsymbol{E}_{S E M}^{*}$

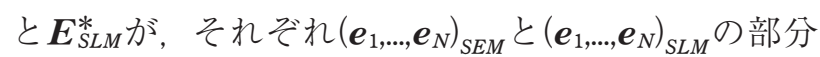
集合からなる行列であるとしょう。このとき, $\boldsymbol{Y}=\boldsymbol{X} \beta+\boldsymbol{E}_{S E M V}^{*}+\varepsilon$ と $\boldsymbol{Y}=\boldsymbol{X} \beta+\boldsymbol{E}_{S L M V}^{*}+\varepsilon$ は, それぞ れSEM と SLM のモデル化に対応する ${ }^{64)}$.

Tiefelsdorf and Griffith $\left(2007 ｛ }^{64)}\right.$ は，ステップワイ ズ法による $\boldsymbol{E}^{*}$ の特定化手法を提案している。 そこ での基準には, 自由度調整済み決定係数最大化基準 とモラン統計量最小化基準がある．SF は，残差の空 間的自己相関最小化基準で固有值ベクトルを選択す るため, 実証研究においては, SEM やSPMに比べて, 残差の空間的な無相関性が満たされやすい.SFア プローチに関する詳細については, Griffith $(2003)^{65)}$, Griffith and Paelinck (2010) ${ }^{66)}$ に詳しい.

\section{（3） 時空間モデル \\ a）時空間モデル：地球統計学}

地球統計データの時空間モデルに関する理論・実 証研究は，近年大きな発展を見せている．

今, 連続な時空間過程 $Y(\boldsymbol{s} ; t)$ における, 時空間過程 モデル $Y(\boldsymbol{s} ; t)=\mu(\boldsymbol{s} ; t)+u(\boldsymbol{s} ; t)$ を考えよう。ここでは, 時間と空間の相互作用を, 共分散関数を通してどの ようにモデル化するかという点が問題となる. 
Cressie and Huang（1999） ${ }^{67)}$ は，時間と空間の相互作 用を考慮した分離不可能 (non-separable) 型の様々な 共分散関数を提案している. 井上ら (2009) ${ }^{68)}$ は, 彼らの共分散関数の一つを用いたクリギング（時空 間クリギング）内挿により，東京 23 区全体の地価 マップを作成し, 時空間クリギングの高い予測正確 度を実証的に示している。しかしながら時空間過程 モデルでは, 確率変数間の自己相関関係を共分散関 数で記述するため, 時間の前後関係が考慮されず, 過去が将来に影響を及ぼすだけでなく, 将来も過去 に影響を及ぼす構造になっている。このアプローチ は, 空間予測の正確度の点では優れているが, 因果 律を考えれば，時間の前後関係を明示的に考慮した アプローチが望ましい場合も多いであろう。

Stroud et al.（2001） ${ }^{69)}$ は，時間方向を離散と見た， 時空間 $Y_{t}(\boldsymbol{s})$ における状態空間モデルを構築し, カル マンフィルタによる実用的なパラメータ推定法を提 案している。 また, 時空間モデルにおいては近年, データ同化 (data assimilation) が重要なトピックの一 つとなっている70)

b）時空間モデル：空間計量経済学

時空間確率場 $\left\{Y_{t}(\boldsymbol{s}): \boldsymbol{s} \in D, t \in T\right\}$ の実現值が，複数 の空間的なユニットで時系列的に得られていると き, このデータはパネルデータと呼ばれ, 空間計量 経済学の分野では，空間データであることを強調し て, 空間パネル（spatial panel）と呼ばれることが多 (71)。パネルデー夕を用いることで, 自由度の上昇 (推定量の効率性の改善), 異質性の考慮, 多重共線 性の改善等が期待できる72)。Elhorst（2003） ${ }^{73)}$ は, 標準的なパネルデータモデルである固定効果モデ ル, ランダム効果モデル, ランダム係数モデルを, 空 間計量経済モデルに拡張している。空間パネルにお ける SLM は,

$$
Y_{i t}=\rho \sum_{j=1}^{N} w_{i j} Y_{j t}+\boldsymbol{x}^{\prime}{ }_{i t} \beta+\mu_{i}+\varepsilon_{i t}
$$

で与えられる。ここで， $\mu_{i}$ は時間不変な地域特有の 項であり，これを固定効果とするか，変量効果とす るかは, ハウスマン検定で判断する。同様に, 空間 パネルにおける SEM（SAR 誤差モデル）は,

$$
\begin{gathered}
Y_{i t}=\boldsymbol{x}_{i t}{ }_{i t} \beta+\mu_{i}+u_{i t} \\
u_{i t}=\rho \sum_{j=1}^{N} w_{i j} u_{j t}+\varepsilon_{i t}
\end{gathered}
$$

で与えられる，通常のパネルモデル同様，空間パネ ルモデルの代表的パラメータ方法も, 最尤法と GMMであり，それぞれ Elhorst (2003) ${ }^{73)}$, Kapoor et al.（2007） ${ }^{74)}$ によって推定法が提案されている。 ま た，時間遅れを考慮した動学的な空間パネルモデル についても, 近年盛んに研究が行われている75).

\section{（4）地球統計学と空間計量経済学の相違}

ここでは, 地球統計学と空間計量経済学の相違に ついて，筆者らの私見も交えて簡単に総括したい．

空間計量経済モデルは，分析者が予め設定する重 从行列 $\boldsymbol{W}$ を通して空間過程を（自己回帰型等に）モ デル化することにより, 通常の計量経済学の膨大な 知見を援用し，モデル化を行えるという点に利点が ある、空間計量経済モデルは，例えば人口等の連続 な空間過程を想定できない社会経済データの分析に おいては, 地球統計モデルに比べて優位性があると いえる。しかしながら $\boldsymbol{W}$ の特定化の誤りが, 分析結 果を大きく左右するという点に本質的な限界があ る。また, Wall $(2004)^{76)}$ が指摘する通り, 空間過程 をモデル化する空間計量経済モデルの方法では, 分 散共分散行列は間接的に求められ，実際の空間パ ターン (構造) が想像しづらい. この点に扔いても 難があると言わざるをえない。しかしながら, 前者 に関しては, ノンパラメトリック HAC 推定 ${ }^{77)}$ や潜 在変数を用いた構造方程式モデリング78)等, $\boldsymbol{W}$ を用 いない方法も発達してきており, 様々なシミュレー ション研究により, 重み行列の選択に関する知見も 積み重ねられつつある ${ }^{79)}$ 。 また, 後者の課題に関し ても, 自己回㷌型が大域的な, 移動平均や誤差構成 要素型が局所的な空間的自己相関を生みだすといっ た，モデル化が生み出す空間パターンの差異に関す る研究も行われているため, 意味解釈のし難さは改 善されつつあると考えられる。しかしながら，例え ば情報幾何の観点からのモデルの位置づけに関する 体系的整理などの余地は残されている.

一方で地球統計モデルは, 空間に連続性と定常性 を仮定し, 分散共分散行列を距離の関数で直接構造 化することで, 空間パターン（構造）に関する直観的 な理解が可能である。例えば, spherical 型の共分散 関数を用いた場合，推定されたレンジをそのまま空 間的自己相関が無くなる位置と解釈することができ るため, 実証研究に打いて有用である場合が多い. しかしながら，定常性の仮定はかなり強い仮定であ るため，特に社会経済データへの適用には問題も多 く, 適用例は未だ少ないのが現状である。この点に ついて, 近年の非定常共分散に関する研究 (deformation アプローチや, 畳み込みカーネル) ${ }^{80) ~ 82) ~ は, ~}$ 地球統計モデルの適用可能性を大きく広げる可能性 を秘めており, 理論的研究の進展と実証研究の蓄積 が望まれる。 
第一章で述べた通り，両分野は，空間という同一 の事象を扱っているにも関わらず，互いの文献を参 照することは少なく，モデリングにおいても，異な る考え方がとられることが多い，空間データモデリ ング・応用空間統計学という統合的な観点からみれ ば，両分野が互いの研究を取り入れながら相互補完 的に発展することで, 互いの短所を補うようなモデ ル開発の余地は十分に残されていよう ${ }^{83)}$.

\section{（5）ソフトウェアの開発動向}

本節では，本章あるいは次章で紹介するような技 法を実際のデータに適用するに当たってのソフト ウェアについて概説する, 以下では, 地球統計学, 空間計量経済学に関する代表的なソフトウェアを概 観する。詳細なレビューについては, Fischer and Getis (2010) ${ }^{84)}$ を，特に R 言語を用いたものについ ては, Bivand (2006) ${ }^{85)}$, Bivandetal. (2008) ${ }^{86)}$, 古 谷（2011）43）を参照されたい. 以下述べるように, 様々なソフトウェアが開発されているが, 商用ソフ トウェアでは, 中身がブラックボックスなものもあ り，使用には注意が必要である。

\section{a) ソフトウェア：地球統計学}

$\mathrm{SPM}$ のパラメー夕推定には, 特に $\mathrm{R}$ が有用であ る。代表的なパッケージは, fields, geoR, geoRglm, gstat， spBayes 等がある。geoRの具体的な使用方法 については, 間瀬 (2010) ${ }^{47)} に$ 詳しい. geoRglmで は，一般化線形モデルを扱うことができる。また, geoRglm, ramps, spBayesでは, パラメータのベイズ 推定が可能となっている，R 以外では, MATLAB の mGstat 等があり，同じくMATLAB 言語で記述され た BMElibでは，時空間モデリングが可能である. GUIベースのソフトウェアには, $\mathrm{SGeMS}^{87)}$, SAGA, gslib 等がある。また, ベイズ推論を行う場合, 複雑 なモデルでなければ, WinBUGS が有用なことが多 く29), 生態学の分野では広く用いられている.

応用的なモデルについて, Rの SemiPar や AdaptFit では, 後述する geoadditive model と呼ばれ る，トレンド項の非線形性を考慮したモデルの推定 が可能である。また, 時空間クリギングには, gstat を用いることができる ${ }^{88)}$ ，その他，非線形モデルを 扱う constrainedKriging, 次元削減モデルを扱う LatticeKrig, spBayes 等のパッケージが存在する。さ らなる詳細については, Hengl (2007） ${ }^{89)}$ 等を参照さ れたい。

\section{b）ソフトウエア：空間計量経済学}

GeoDaCenter (https://geodacenter.asu.edu/) では, 空 間計量経済分析のためのソフトウェアが開発・更新 されている，代表的なソフトは，GUIベースの
GeoDa である. 現在, GeoDa と共に, 用いられるこ とが多いのが，Rである，Rの spdep では， SEM, SLM, SDM, SAC 等の標準的なモデルが推定可能で あり，SFアプローチに拈ける固有ベクトルの選択を 行う関数も備えている ${ }^{90)}$. GWR モデル, HAC 推定 はそれぞれ, spgwr, sphet ${ }^{91)}$ で推定可能である. 同様 に, MATLAB も用いられることが多く, 様々な関数 が空間計量経済学の研究者の HP で公開されている. 例えば, J. LeSage 教授の spatial econometrics toolbox では，SEM，SDM，SLM等の標準的なモデルが推定 可能であり, パラメー夕推定法としてベイズ推定が サポートされている。 また, K. Pace 教授の spatial statistics toolbox では, 最尤法に基づく大規模デー夕 のパラメータ推定関数が提供されている. その他, Stata も実証研究では用いられることが多く92), R. Franzese Jr. 教授も, HPで様々なコードを公開して いる(Matlab/stata)。近年では, Pythonを用いた PySal や GeoDaSpace の開発が精力的に進められてい 万$^{93)}$

応用的なモデルについては，公開されたコードは 多くはない. 空間 2 項ロジット/プロビットモデル については, 前述の spatial econometrics toolbox や, R の McSpatial, spatialprobit が使用できる.しかしな がら空間多項離散選択モデルは発展途上であるた め, 現時点で公開されているソフトウェアはないと 思われる。空間パネルモデルに関しては, P. Elhorst 教授が, ダイナミックパネルを含む空間パネルの推 定や検定に関するMATLAB の関数を提供してい る ${ }^{94)}$.また, Rの splmでも, 標準的な空間パネルモ デルが推定可能である.

\section{4. 土木計画に関連する応用空間統計学の実証研 究と課題}

\section{（1）実証研究のレビュー方針}

地球統計学・空間計量経済学に関連した実証研究 は膨大であり, レビューの対象は, ある程度絞らざ るを得ない。本稿では特に, 土木計画に関連が深い, ヘドニック・アプローチによる不動産価格の分析, 地域格差・経済成長・経済集積の分析, 交通ネット ワークモデル・離散選択モデル・空間相互作用モデ ルへの適用, 視覚化, データ変換への応用に限定す ることとする。もちろん, 重要な実証研究はこれら に留まるものではなく, 例えば, 空間的な価格競 ${ }^{\text {争 }}{ }^{95)}$, 環境クズネッツ曲線の推定 ${ }^{96)}$, 産業連関分析 への応用 ${ }^{97)}$, 自治体間競争 ${ }^{89)}$, マーケティング分野 への応用 ${ }^{99)}$ 等, 様々な興味深いトピックがあること 
を指摘しておきたい。また，社会ネットワーク分析 の分野では, 空間計量経済モデルと非常によく似た 定式化によって, 社会や組織間のネットワークの影 響を分析する理論・実証研究が蓄積されている。そ こでは, Manski (1993) ${ }^{100)}$ の議論に基づき, パラメー 夕の識別により重点が置かれている101).

（2）ヘドニック・アプローチによる不動産価格の分析 a）ヘドニックモデルと空間的自己相関

不動産を対象としたへドニック価格関数の推定に おいて空間的自己相関を考慮する試みは，既にCan (1990) ${ }^{102)}$, Dubin (1988) ${ }^{52)}$ によって行われていた. ここで, 前者は空間計量経済学の分野のモデルを用 いており, 後者は地球統計学の分野のモデルを用い ている。我が国でも，高塚・樋口（1996） ${ }^{103)}$ は，早 い段階から空間計量経済モデルを用いて地価に関す る実証分析を行っている。，その後，両分野の多くの モデルがへドニック価格関数の推定に応用され，有 用性が確認されている(例えば, 空間計量経済

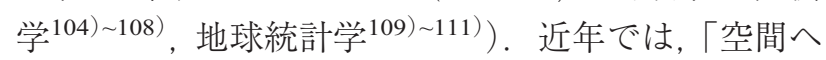
ドニック・アプローチ (spatial hedonic approach)」と いう言葉も定着しつつある ${ }^{112) ~ 114)}$

Zietz et al.（2008） ${ }^{115)}$ は，SLM を分位点回帰モデ ルに適用し，属性が価格に与える影響の価格帯によ る差異を分析している。 Zhuetal. (2011) ${ }^{116)}$ は, 画 像処理の手法を用いて，SEMにおいて異方性を考慮 し、ヘドニックモデルに適用している. Jeanty et al. (2010) $\left.{ }^{117}\right)$ は，連立方程式型の空間計量経済モデル を構築し，住宅価格と人口の相互作用を分析してい る. Seya and Tsutsumi (2010) ${ }^{118)}$ は, 地球統計モデル の枠組みで, 従属変数, 説明変数の欠損デー夕をパ ラメータとみなし, ベイジアンマルコフ連鎖モンテ カルロ法 (Bayesian Markov Chain Monte Carlo (MCMC) method）を用いて復元する方法論を提示している. 植杉 (2011) ${ }^{119)}$ は, パラメータの時間可変性を考慮 したSLMを用いて, 小地域における不動産インデッ クスを考案している. Banerjee et al. (2004) ${ }^{120)}$ は, 定常過程の重み付き和として, 非定常な空間過程を モデル化し，SPMに基づくへドニックモデルを構築 している. Fernandez (2011) $\left.{ }^{121}\right)$ は, 最も標準的な金 融モデルの一つである資本資産価格モデル（capital asset pricing model (CAPM) ) に, SLM を組み合わせ たモデルを構築している.

ヘドニックモデルにおいては, 関数形の特定が非 常に重要な問題となる ${ }^{122)}$. Geniaux and Napoléone (2008) ${ }^{123)}$, 瀬谷ら (2011) ${ }^{124)}$ は，それぞれ関数形 の非線形性と誤差項の空間的自己相関を考慮した geoadditive model ${ }^{125)}$ と呼ばれるセミパラメトリック
モデルをへドニックモデルに適用し，その有用性を 実証している。 McMillen (2010) ${ }^{126)}$ は, SLM のセミ パラメトリックモデルへの拡張を試み, ヘドニック モデルへの適用例を示している. Baltagi and Li (2004) ${ }^{127)}$ は, SLM の Box-Cox 変換に関する LM 検 定の方法を提示している。単変量の応用空間統計モ デルは, 基本的には一座標に一つの観測值が対応す る。しかしながら，例えば戸別マンションを考える と, 一座標に, 複数の戸が対応し, その数は物件に よって異なるため, 空間的自己相関のモデル化が難 しくなるという問題がある。これに対して, Gelfand et al. (2007) ${ }^{128)}$, Corrado and Fingleton (2012) ${ }^{61)}$, 山形ら (2011) ${ }^{129)}$ は，それぞれマルチレベルモデル を援用することでこの問題に対処している.

不動産デー夕は, 取引位置が空間的に固定されて いないため, 前述の空間パネルモデルを適用するこ とが難しい点も問題になる。これに対して Pace et al. (1998) ${ }^{130)}$ は定点観測でないマンション価格デー タへの適用が可能な時空間線形モデル (spatio temporal linear model (STLM) ) を提案している. Pace et al. (1998) ${ }^{130)}$ のモデルは, 連続な時空間上でのモデ ル化が可能であるため, 観測值は時間的にも空間的 にも定点観測されている必要がない。また，すべて の観測值を古い順に並び変え, 時空間上の一方向の 影響とする（過去からの影響に限定）ことで, 尤度関 数のヤコビアン項の対数が 0 となり, OLSにより回 帰係数の一致推定量が得られるという実用上の利点 もある. Pace etal. (1998） ${ }^{130)}$ のモデルは様々な拡張 が加えられ, 現在までに様々な地域を対象とした実 証研究が行われている ${ }^{131) ~ 133)}$ ，不動産市場の空間 デー夕分析に関する詳細については, Pace et al. (1998) ${ }^{134)}$ のレビューを参照されたい.

\section{b）空間ヘドニックモデルと回帰係数推定值の解釈}

地球統計モデル, 空間計量経済モデルの優劣は一 般につけられるものではなく, 使用目的によって異 なる，例えば，予測・内挿を目的とする場合は，前者 のアプローチを用いる方が自然である，また，本項 で述べるとおり, 社会資本整備の便益評価において も，前者のほうが柔軟な評価につながると考えられ る. 一方で, 前述の通り SEM P SPM 等の誤差項に 関するモデルは, 経済理論的な理由よりは, 測定誤 差が空間的な意味で系統的に存在する等のデータの 問題を処理する目的で用いられることが多いため, 経済学的な意味解釈を行う目的では, SLMの方が有 益であるという指摘がされている。例えば, Fingleton and López-Bazo（2006） ${ }^{135)}$ は, 地域成長モ デル $(\beta$-収束モデル) の文脈で, 地域間のスピルオー バー効果をランダムショックとしてモデル化する 
SEM 型のモデルを用いた実証研究をアドホックと批 判している. Small and Steimetz（2012）113)は, 金銭 的・技術的外部性の観点から, 空間計量経済学の分 野の SLM を用いたへドニックモデルに経済学的な 解釈を加えている。しかしながら, Small and Steimetz (2012） 113)の意味での金銭的・技術的外部性のどち らが生じているかを判断することは実際には困難で あるため, SLM は便益評価において使いづらいとい う問題もある ${ }^{114)}$.

\section{（3）地域格差・経済成長分析, 経済集積の分析 a) $\beta-\sigma$ 収束}

$\beta-\sigma$ 収束アプローチは, 地域の成長, 所得格差に 関する標準的な分析手法の一つである（例えば, 江 尻ら, 2001） 136）。Rey and Montouri（1999） 137)は, 近 隣地域は似通った成長パターンを示すと考え, $\beta$ 収 束アプローチに空間計量経済モデルを適用してい る。同様に, Rey and Dev (2006) ${ }^{138)}$ は $\sigma$ 収束アプロー チにおいて空間的自己相関を考慮している。その 後, 現在までに空間計量経済モデルを $\beta-\sigma$ 収束アプ ローチに適用した膨大な数の実証研究が行われてい る. Abreu et al. (2004) ${ }^{139)}$ は，それらに関するレ ビューを行っている。

Fingleton and López-Bazo（2006） ${ }^{135)}$ は，空間計量 経済モデルを用いた経済成長モデルの実証の多く が, 空間的自己相関をアドホックな方法で処理して いると指摘している。これは, 経済理論的根拠なし に, 空間的自己相関をランダムショック (SEM) とし て処理する方法に対する批判である。一方, López-Bazo etal. (2004） 140), Vayá etal. （2004）141) は，経済理論モデルから，SDMに類似した実証モデ ルを導いている. Seya etal. (2012) ${ }^{56)}$ は, Vayá etal. (2004） 141）を拡張し, 地域の経済的な大きさの差異 を考慮するために，非対象の $W$ を用いている（非対 称な $W$ では, 空間パラメータの取り得る範囲におい て注意が必要となる ${ }^{28)}$ ). 同様に, 近年の研究では, まず理論モデルを構築し，そこから実証モデルを導 く例が多くなっている. Pfaffermayr (2009) 142) は,

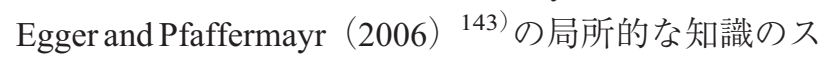
ピルオーバーモデルは，通常の回帰モデルに説明変 数のラグ項を加えた spatial cross-regressive model （SCM）で検証でき， Ertur and Koch（2007）144）の大 域的な知識のスピルオーバーモデルは, SDM で検証 できるとしている。これらの差異は, 理論モデルの 生産関数において, 知識のスピルオーバーをどのよ うに定式化するかによって生まれる145),56)。

b）経済集積の分析

中村（2008）146)は, 都市, 地域における経済集積
の様々な測度をレビューしたものであり，そこでは 「空間的自己相関に関しては Cliff and Ord（1981）147） に代表されるように, 実は 1980 年代に精力的に議論 されてきた。しかしながら, 近年, 新経済地理学の 隆盛によって空間分析を試みる研究者から再び注目 を集めるようになっている」と指摘している. Arbia (2001) 148) も同様に，空間的集中（spatial concentration) に関する研究の多くが, 立地ジ二係数等の非空 間測度に基づくにとどまっていると指摘し，モラン の $I$ 統計量 ${ }^{149)}$ や Getis-Ord の $G$ 統計量 ${ }^{150)}$ の有用性 を具体例で示している。 Rey and Janikas $(2006)^{151)}$ は, 同様の問題意識のもと, 空間的自己相関を考慮した 新たなジ二係数とタイル指数を考案し, ソフトウエ アとして公開している. Kelejian and Mukerji (2011) 152) は, 動的な空間的スピルオーバーに関す る 2 つの指数---[i]ある地域で発生したイベントが, 周辺地域にどのように波及するか，[ii]ある地域が， 周囲の地域で発生したイベントからどのような影響 を受けるか, を考案している。

局所的な空間的自己相関の診断統計量（local indicators of spatial association（LISA））を用いた，集積の 視覚化やホットスポットの統計的検出に関する研究 も様々なものが行われている. Guillain and Le Gallo (2010) 153) は，ローカルモラン統計量 ${ }^{154)}$ を用いて, セクター毎の空間的集中の度合いを視覚化してい る. Rusche etal. (2011）155) はさらに, Bivariateロー カルモランを用いて, セクター間の共集積の分析を 行う方法を提示している。（時）空間点過程を用いた 産業集積に関する関する研究も, 近年知見が蓄積さ れつつある156) 158)

産業集積においてフェイス・トゥ・フェイスのコ ミュニケーションが重要な役割を果たすという都市 経済学の知見に基づけば，交通トリップのデータか ら産業集積を検証するというのは，一つの自然なア プローチであろう。このような研究に, 東京都市圏 パーソントリップ調査の目的別業務トリップからト リップ集積の分析を行った村上ら（2011）159），村上 ら (2012) 160) が挙げられる。このうち前者は, Ord and Getis（1995）161）, 後者は Rogerson（1999） ${ }^{162 ） の ~}$ LISAを用いている。

\section{（4）交通ネットワークモデルへの適用}

地球統計モデル, 空間計量経済モデルは, リンク 交通量や，リンク上の速度の簡易推計に用いられる ことが多い. 動的交通量配分 ${ }^{163)}$ においては, ネット ワークデータの構築や動的 OD の取得に多大なコス トがかかるため, 簡易推計のために, 統計モデルに 基づく子測を行うことも重要であるといえる. 
Hackney et al. (2007) ${ }^{164)}$ は, 道路のリンク速度をリ ンク種別，時刻，空間構造の関数として説明する空 間回帰モデル（SLM）を構築している。 Kamarianakis and Prastacos（2003） ${ }^{165)}$ は, 時空間 ARIMA モデル4) を用いて，交通流予測を行い，ARIMA モデルに比べ た予測精度の向上を示している. Wang and Kockelman (2009) ${ }^{166)}$ は, トラフィックカウンター データをクリギング外挿 (extrapolation) することに より，交通量を高い正確度で予測することに成功し ている. Miura (2010) ${ }^{167)}$ は, 2 地点間の最短旅行時 間の予測にクリギングを適用している.

\section{（5）多肢離散選択モデルへの適用}

離散選択モデルに関連する分野において, 多項口 ジットモデルの IIA 特性の緩和は, 重要な研究テー マであった. Schuessler and Axhausen (2007） ${ }^{168)}$ は, 選択結果や意思決定主体の類似性の導入について, 詳細にレビューを行っている，そこでは，空間的自 己相関の考慮が，一つの方法として紹介されている。 Mohammadian etal. (2005) ${ }^{169)}$ は, 多項ロジットモデ ルの確定項に, 距離の減衰関数として, 他主体の行 動の結果の観測值を導入することで, 選択結果の空 間的な自己相関を考慮している。しかしながら，他 主体の行動の観測值の条件付きという定式化は, 予 測の観点からは使用しにくいという問題がある ${ }^{170)}$. Miyamoto etal. (2004) ${ }^{171)}$ は, mixed logit model のフ レームで, 効用確定項間の空間的自己相関と, ガン ベル分布に従う誤差項の空間的自己相関の両者を考 慮し, 最尤法に基づくシミュレーションベースのパ ラメータ推定法を考案している. Smirnov and Egan (2011) ${ }^{172)}$ は，同様に効用確定項間の空間的自己相 関を考慮し, 最尤法によるパラメー夕推定法を提示 している. 空間多項ロジットモデルの最尤法による パラメータ推定は計算負荷が大きいため, GMMに 基づく簡易法も提案されている ${ }^{173)}$ 。一方, 近年の計 算機の発達により, シミュレーションを用いて, 多 項プロビットモデルを構築することが容易になりつ つある. 屋井・中川 (1993） ${ }^{174)}$ は, 多項プロビット モデルに扔いて分散共分散行列を構造化した構造化 プロビットモデルを提案し, 経路選択モデルや目的 地選択モデルでの定式化例を示している. Chakir and Parent $(2009)^{175)}$ は, 効用（彼らの文脈では利潤）の 確定項の空間的自己相関を考慮し，パラメータをべ イジアン MCMC 法に基づいて推定している.

\section{（6）空間相互作用モデルへの適用}

空間相互作用モデルの基本である重力モデルは, フローの観測值がそれぞれ独立であると仮定してお
り, 空間データの性質である空間的自己相関を考慮 していない，そのため空間的自己相関が存在する場 合に拈いては, パラメータ推定值の信頼性が低下す

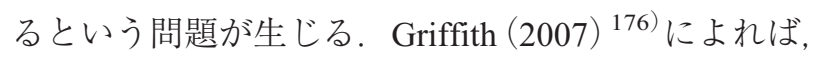

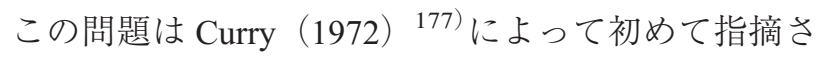
れ，その後カナダの通勤フローに関する実証研究を 行った Griffith and Jones (1980) ${ }^{178)}$ でもこの問題が指 摘されている。この様な背景から, フローにおける 空間的自己相関を考慮したモデル化に関する研究が 近年盛んに行われている. 特に LeSage and Pace (2008) ${ }^{179)}$ は, 空間計量経済学の手法を用いたモデ ルを提案し, 海外の様々な実証研究においてその有 用性を示している.

前述の通り, 点・面データにおいては, 地域間の近 接性は $N \times N$ の空間重み行列で表すことができる. LeSage and Pace (2008) ${ }^{179)}$ は, フローを発地と着地 のペアと考えるのではなく, 一つの観測值として捉 えるという発想により, 空間重み行列を構築した。 すなわち, ある発地 $i$ から着地 $j$ のフローが存在す るとき, (a) 発地 $i$ 周辺から着地 $j$ へのフロー, (b) 発 地 $i$ 加着地 $j$ 周辺へのフロー, そして (c) 発地 $i$ 周 辺から着地 $j$ 周辺へのフロー, という三つの場合に分 けて考えている. LeSage and Pace (2008） 179)のモデ ルは誤差項に正規分布を仮定した対数正規重力モデ ルをベースとしている. Tsutsumi and Tamesue（印刷 中) ${ }^{180)}$ は, 対数正規重力モデルにおいて, 内々フロー の欠損を, EMアルゴリズムを用いて復元する方法 を提示している。そそこでは，空間的自己相関を考慮 することで, 内々フローの復元精度が大幅に改善す ることが示されている.

\section{（7）空間データの視覚化}

古谷 (2004) ${ }^{181)}$, Huang etal. (2010) ${ }^{182)}$ は, GWR を用いて、ヘドニックモデルを構築し, パラメータ の空間分布に関して考察を与えている. GWRの回 帰係数の地理的なマッピングに拈いては, その色分 けの階級区分が重要となる。これについては, Mennis (2006) ${ }^{183)}$ が詳細な検討を行っている. 前述 の井上ら (2009） ${ }^{68)}$ は, 東京 23 区の公示地価を, Cressie and Huang (1999） ${ }^{67)}$ の共分散関数に基づく時 空間クリギングを用いて推計し, 70 年代からの地価 分布図のアニメーションを作成している。同様に, Tsutsumi et al. (2011) ${ }^{184)}$ は東京都市圈全域を対象と した地価マップの作成を試みている。地価マップの 作成においては, 予測点に扔ける説明変数を如何に 取得するかという点が課題となる. Tsutsumi et al. (2011) ${ }^{184)}$ は, 任意地点で容易に取得できる土地利 用・アクセシビリティ変数のみを用いているが，（ク 
ロスセクションデータを用いていることもあり), 郊 外部に扮ける過大推計の問題を抱えている。井上ら ${ }^{(2009 ）}{ }^{68)}$ は, 説明変数自体をトレンド項なしの OK で内挿することで取得している. 今後, 説明変数の 予測における誤差を, errors in variable として処理す る新たなクリギング手法が求められよう。そのよう な取り組みとして, 例えば Anselin and Lozano-Gracia

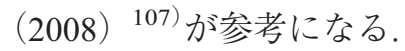

Tsutsumi and Seya $(2008)^{185)}$ は, 鉄道開業前後の地 価をクリギング内挿し，それを時系列的に観察する ことで，アナウンスメント効果について考察してい る. Páezetal. (1998) ${ }^{186)}$ は, ヒートアイランド現象, Alesheikh and Omidvari (2011) ${ }^{187)}$ は道路交通からの 騒音のクリギングによるマッピングを試みている. Kerry etal. (2010) ${ }^{188)}$ は, ポアソン・クリギングと呼 ばれるカウントデータに対するクリギング手法を用 いて，犯罪率マップの作成を試みている.

視覚化においては, 今日でも計算負荷が問題とな ることが多い. 特に, 時空間クリギングでは, $N T \times N T$ 逆行列を計算する必要がある。これに 関して近年, 空間過程を低次元のベクトルや行列で 表現することによる次元削減が, 空間統計学の重要 なトピックとなっている ${ }^{189)}$ 。また, 近年計測デー夕 の取得可能性の高まりとともに, 日々集められてい くデー夕を, その時空間解像度や信頼度 (精度・正確 度）を考慮しながら組み合わせていくことが求めら れている. 複数のデータソースからの空間データの モデリングについては, Hall (2004) 190), Nguyen (2009) ${ }^{191)}$ が参考になる。予測值だけでなく, 予測 における誤差分散（クリギング分散）は，重要な情報 である，例えば，観測点配置の再計画等に用いるこ とは有用である192),193)。

\section{（8）空間データの変換への応用}

観測データが得られている空間単位と実際に興味 のある空間単位の乘離の問題は, 実証研究に打いて 分析者を悩ませる大きな課題の一つであり, 必要に 応じてデータの変換を行うことが要求される (change of support problem (COSP)) (Gotway and Young, 2002） ${ }^{194)}$. 集計デー夕の変換では, 従来, 面積按分 のような極めて素朴な方法が広く用いられてきた。 しかし，第 2 章で述べたような空間データに内在す る空間的自己相関や空間的異質性を考慮すること で, より精度の高いデータの単位変換: 面補間 (areal interpolation) ${ }^{195)}$ が可能となる。

地球統計学の手法を用いた面補間においては, 連 続的な空間過程から得られる確率变数をゾーンに集 計するため, ブロック・クリギングの手法を用いる
ものが多い37). 代表的な手法の一つが, Area to point kriging ${ }^{196)}$ であり, 犯罪マップの作成等に用いられて いる188)。他にも, 地球統計学の手法を応用した様々 な面補間法が提案されている197) 199). Nagle $(2005)^{37)}$ は, 社会経済データへの適用を目的として, 連続な空間過程を集計する方法について詳細に論じ ている。

一方, 空間計量経済学の手法を応用した面補間法 は，筆者らがレビューした範囲では, Polasek and Sellner $(2010)^{200)}$ と堤・村上 $(2010)^{201)}$ が存在する. 前者は, 時系列解析で 40 年以上の歴史を持つ Chow-Lin モデルの自然な応用である，後者は，SLM に基づき, ある集計単位から別の単位（配分単位）に 集計量の変換 (面補間) を行う最尤法 (EM) アルゴ リズムを考案している。 そこでは, 集計単位と配分 単位のポリゴンをインターセクトした細分単位にお いて空間的自己相関を考慮し, 配分単位に集計する 方法がとられている。回帰モデルに基づく面補間で は, 用いられる説明変数により, 配分単位の予測值 が大きなばらつきをもつことが多い. 空間ラグ項の 導入は, このようなばらつきを一定程度スムージン グする効果を持つと考えられる。

\section{5. おわりに}

前述のように, 応用空間統計学の手法を用いて 様々な実証研究が行われており, 我が国への適用事 例も少しづつ増えている。 そのような状況の中で, 堤・瀬谷 (2012) ${ }^{28)}$ においては理論研究を中心にレ ビューを行い, 既存研究を整理した。一方, 本稿で は実証研究を中心にレビューを行い, 最新の研究動 向や課題を整理しながら, 土木計画に扔ける応用空 間統計学の可能性について論じることを試みた。

空間デー夕分析は, 様々な分野に関わるため, 分 野において用いる用語やモデルの前提等で不一致が 見られ，これが新規の研究者や実務者の混乱を招い ている側面も見受けられる。一例を挙げれば, 前述 のSLM（空間ラグモデル）は, 空間計量経済学の代 表的テキストの中でも, spatial lag model ${ }^{15)}$, mixed regressive spatial autoregressive model ${ }^{13)}$, spatial autoregressive model $(\mathrm{SAR})^{14)}$ と様々な呼称を持つ ${ }^{49)}$. ま た, SEM (空間誤差モデル) は, 空間統計学のテキス ト4)では, simultaneous autoregressive model（SAR）と 呼称され, conditional autoregressive model (CAR) と 比較される形で導入されている。従って, SARが, 空間ラグモデルを表わすのか, 空間誤差モデルを表 わすのかは, 執筆者の背景によって異なる。それゆ 
え, 本稿で用いた呼称が, 必ずしも一般的であると は限らないことに留意されたい。

柏谷 $\left(1996\right.$, p. 31） ${ }^{202)}$ は, 土木計画学の意義につ いて，「土木計画学というフィールドを我々があえて 主張する場合には公共土木事業における社会的意識 決定に関するさまざまな事象の分析が主な研究対象 であると言えるのではないだろうか.」と述べてい る. 拙稿の堤・瀬谷 (2010) ${ }^{114)}$ は, まさに公共土木 事業の評価への応用空間統計学の適用という問題意 識に基づくものである。第 4 章で議論したとおり, これまでにも土木計画に関連した数多くの研究が展 開しているが，未だ取り組むべき課題が多く残され ているのも事実である。例えば，土地利用モデルあ るいは応用都市経済（CUE）モデルのような大規模 な計量モデルにおいて空間データをどのように扱う かは，依然として残されている大きな課題の一つで ある (堤, 1997 ${ }^{203)}$ 。このように, 土木計画の視点か ら応用空間統計学に関する独自の研究テーマを発掘 する余地は大きい，本稿が土木計画における応用空 間統計学の実用化と応用の促進に少しでも貢献する ことを願う次第である。

謝辞: 本稿は, 第 44 回土木計画学研究発表会での招 待講演原稿を再構成したものである. 講演の機会を いただいた，土木計画学研究委員会に謝意を表した い. 筆者らの応用空間統計学の研究は, 堤が博士課 程在学中に東京大学教授の清水英範先生に指導を受 けたことに始まる。またその時, 現・東北大学教授 (当時広島大学) の奥村誠先生から空間計量経済学に ついて紹介を受け, その後, 清水先生から地球統計 学について紹介を受けたことが, 今日に至る研究に 直接繋がっている，さらに，現・広島大学准教授の 塚井誠人先生が平成 16 年度土木計画学研究・発表会 において「空間統計モデルのフロンティア」と題す る招待講演をされたことが, 筆者らが応用空間統計 学の研究を再開するきっかけとなった。これらの先 生方, さらには東北大学教授の安藤朝夫先生を始め とする何人もの先生方から, 絶えず, 研究会や学会 等に扔いて有益な意見を賜わり, 現在も研究者仲間 として大いに刺激を受けている。筆者の二人が現在 所属する筑波大学では, 特に教授の石田東生先生・ 故吉田あつし先生から有益な助言を賜る機会が多く あった。 また, 堤が所属していた東京大学において は, 現・政策研究大学院大学特別教授の森地茂先生 から示唆に富む助言を賜った。さらに, 瀬谷が所属
する国立環境研究所の山形与志樹様からも, 多くの 助言・協力を賜っている. 紙面の都合でその他の全 員の扮名前を挙げることが出来ないことを拈許し願 いつつ, これら多くの方々に対し, この場を借りて 心から感謝と扮礼の言葉を申し上げたい。

\section{参考文献}

1) Goodchild, M. F., Anselin, L., Appelbaum, R. P. and Harthorn, B. H. : Toward spatially integrated social science, International Regional Science Review, Vol. 23, No. 2, pp. 139-159, 2000.

2) Matheron, G. : Principles of geostatistics, Economic Geology, Vol. 58, No. 8, pp. 1246-1266, 1963.

3) 間瀬茂, 武田純：空間データモデリング, 共立出版, 2001 .

4) Cressie, N. A. C.: Statistics for Spatial Data, Revised Edition, New York, Wiley, 1993.

5) Wackernagel, H.: Multivariate Geostatistics: An Introduction with Applications, 2nd ed., Berlin, Springer-Verlag, 1998, (地球統計学研究会訳編, 青木 謙治監訳：地球統計学, 森北出版, 2003).

6) Tobler, W. : A computer movie simulating urban growth in the Detroit region, Economic Geography, Vol. 46, No. 2, pp. 234-240, 1970.

7) Curry, L. : A note on spatial association, The Professional Geographer, Vol. 18, No. 2, pp. 97-99, 1966.

8) Cliff, A. D. and Ord, J. K. : Model building and the analysis of spatial pattern in human geography, Journal of the Royal Statistical Society Series B, Vol. 37, No. 3, pp. 297-348, 1975.

9) 奥野隆史編：都市と交通の空間分析, 大明堂, 1996.

10) Haining, R. P. : Spatial autocorrelation and the quantitative revolution, Geographical Analysis, Vol. 41, No. 4, pp. 364-374, 2009.

11) Haining, R. P. : Spatial Data Analysis in the Social and Environmental Sciences, Cambridge, Cambridge University Press, 1990.

12) Haining, R. P. : Spatial Data Analysis: Theory and Practice, Cambridge, Cambridge University Press, 2003.

13) Anselin, L. : Spatial Econometrics: Methods and Models, Dordrecht, Kluwer, 1988.

14) LeSage, J. P. and Pace, R. K. : Introduction to Spatial Econometrics, Boca Raton, Chapman \& Hall/ CRC, 2009.

15) Anselin, L. and Bera, A. K. : Spatial dependence in linear regression models with an introduction to spatial econometrics, Handbook of Applied Economic Statistics ( eds. Ullah, A. and Giles, D. E. ), pp. 237-289, New York, 
Marcel Dekker, 1998.

16) Fujita, M., Krugman, P. and Venables, A. J. : The Spatial Economy: Cities, Regions and International Trade, Cambridge, MIT Press, 1999, (小出博之訳 : 空間経済 学-都市・地域・国際貿易の新しい分析，東洋経済新報 社, 2000).

17) Anselin, L. : Thirty years of spatial econometrics, Papers in Regional Science, Vol. 89, No. 1, pp. 3-25, 2010.

18) 佐々木公明：モデル推定に関する計量経済学的課題, 第 18 回土木計画学シンポジウム「都市の土地利用モ デル」, 土木学会土木計画学研究委員会, pp. 121-124, 1984.

19) 田中和子：都市地理学における土地利用の空間分析, 第 18 回土木計画学シンポジウム「都市の土地利用モ デル」, 土木学会土木計画学研究委員会, pp. 101-109, 1984.

20）奥村誠，足立康史，吉川和広：空間相互作用をとりい れた地域モデルの推定法, 土木計画学研究・論文集, Vol. 7, pp. 115-122, 1989.

21）塚井誠人，江尻良，奥村誠，小林潔司：社会資本の生 産性とスピルオーバー効果, 土木学会論文集, No. 716/ IV-57, pp. 53-67, 2002.

22）梶谷義雄，多々納裕一，岡田憲夫，松田曜子：時空間 統計モデルを用いた人口分布変動に基づく災害復興 過程の分析, 土木学会論文集, No. 772/IV-65, pp. 143-151, 2004.

23) 大庭哲治, 柄谷友香, 中川大, 青山吉隆 : 京町家集積 の近隣外部効果に関する研究, 土木学会論文集 $\mathrm{D}$, Vol. 62, No. 2, pp. 227-238, 2006.

24）塚井誠人, 小林潔司：長期記憶性を考慮した社会資本 の生産性測定, 土木学会論文集 D, Vol. 63, No. 3, pp. 255-274, 2007.

25) 大島英幹, 古谷知之, 福井弘道: 国際航空路線開設自 由化の地域内総生産・炭素排出量への影響分析，運輸 政策研究, Vol. 12, No. 2, pp. 26--32, 2009.

26) 塚井誠人：空間統計モデルのフロンティア，土木計画 学研究·論文集, Vol. 22, No. 2, pp. 1-13, 2005.

27) Anselin, L. : Some further notes on spatial models and regional science, Journal of Regional Science, Vol. 26, No. 4, pp. 799-802, 1986.

28）堤盛人, 瀬谷創：応用空間統計学の二つの潮流：空間 統計学と空間計量経済学, 統計数理（特集「時空間統 計解析：新たなる分野横断的展開」), Vol. 60, No. 1, pp. 3-25, 2012.

29) Banerjee, S., Carlin, B. P. and Gelfand, A. E. : Hierarchical Modeling and Analysis for Spatial Data, Boca Raton, Chapman \& Hall/ CRC, 2004.

30) Schabenberger, O. and Gotway, C. A. : Statistical Methods for Spatial Data Analysis, Boca Raton, Chapman \& Hall/ CRC, 2005.

31) Cressie, N. A. C. and Wikle, C. K. : Statistics for SpatioTemporal Data, New York, Wiley, 2011.

32）上田貴夫, 本城勇介, 波田野敬, 坂口修司: 造成工事 における残留沈下量の平面的予測および誤差，土と基 礎, Vol. 34, No. 6, pp. 51-58, 1986.

33）永田茂, 片山恒雄 : 確率論的手法を用いた地震動強度 分布の推定, 生産研究, Vol. 43, No. 9, pp. 394-397, 1991.

34）宝馨，岡明夫：回帰分析及び kriging による確率雨量の 地域総合化, 土木学会論文集, No. 456/ II-21, pp. 1-10, 1992.

35) 本多眞, 菊地宏吉, 鈴木哲也, 水戸義忠：周辺地 下水位変動の時空間解析のための時空間 Cokriging の 開発と適用, 土木学会論文集, No. 659/ III-52, pp. $283-295,2000$.

36) 本多眞, 山本真哉, 櫻井英行, 鈴木誠, 真田祐幸, 杉 田裕, 松井裕哉：地球統計学的手法を用いた地下水水 質分布の推定とその不確実性の評価, 土木学会論文集 C, Vol. 66, No. 3, pp. 609-624, 2010.

37) Nagle, N. : Continuous field statistical methods for spatial analysis in the social sciences, Dissertation, University of California, Santa Barbara, 2005.

38) Haining, R. P., Kerry, R. and Oliver, M. A. : Geography, spatial data analysis, and geostatistics: an overview, Geographical Analysis, Vol. 42, No. 1. pp. 7-31, 2010.

39) 中谷友樹, 矢野桂司: 犯罪発生の時空間 3 次元地図 ひったくり犯罪の時空間集積の可視化一, 地学雑誌, Vol. 117, No. 2, pp. 506-521, 2008.

40) 畠俊郎, 宮田喜壽, 本城勇介：点過程モデルを用いた 地下水質監視井戸の配置計画, 土木学会論文集 $\mathrm{G}$, Vol. 62, No. 1, pp. 1-8, 2006.

41) 間瀬茂, 尾形良彦, 種村正美 : 点配置データの統計一 理論と応用の現状 -, 数学, Vol. 44, No. 3, pp. 193-204, 1992.

42) Diggle, P. J. : Statistical Analysis of Spatial Point Patterns, 2nd edition, London, Arnold, 2003.

43) 古谷知之：Rによる空間データの統計分析, 朝倉書店, 2011.

44) 歳森敦：空間効果型自己回帰モデルの多変量化と地域 医療費分析への適用, 日本建築学会計画系論文集, No. 554, pp. 153-158, 2002.

45) Anselin, L.: Spatial econometrics, A Companion to Theoretical Econometrics (eds. Baltagi, B. ), pp. 310-330, Oxford, Blackwell, 2001.

46) Fotheringham, A. S., Brunsdon, C. and Charlton, M. E. : Geographically Weighted Regression: The Analysis of 
Spatially Varying Relationships, Chichester, Wiley, 2002.

47) 間瀬茂：地球統計学とクリギング法, オーム社, 2010.

48) Ord, J. K. : Estimation methods for models of spatial interaction, Journal of American Statistical Association, Vol. 79, No. 349, pp. 120-126, 1975.

49) Arbia, G. : Spatial Econometrics: Statistical Foundations and Applications to Regional Growth Convergence, New York, Springer, 2006.

50) Brueckner, J. K. : Strategic interaction among governments: An overview of empirical studies, International Regional Science Review, Vol. 26, No. 2, pp. 175-188, 2003.

51) Anselin, L. : Spatial econometrics, Palgrave. Handbook of Econometrics: Volume 1 (eds. Mills, T. C. and Patterson, K. ), pp. 901-969, Palgrave Macmillan, Basingstoke, 2006.

52) Dubin, R. A. : Estimation of regression coefficient in the presence of spatially autocorrelated error terms, The Review of Economics and Statistics, Vol. 70, No. 3, pp. 466-474, 1988.

53) Islam, K. S. and Asami, Y. : Addressing structural instability in housing market segmentation of the used houses of Tokyo, Japan, Procedia Social and Behavioral Sciences, Vol. 21, pp. 33-42, 2011.

54) Elhorst, J. P. : Applied spatial econometrics: Raising the bar, Spatial Economic Analysis, Vol. 5, No. 1, pp. 9-28, 2010a.

55) 山形与志樹, 村上大輔, 瀬谷創, 堤盛人, 川口有一郎 : 環境性能評価が不動産価格に与える影響の時空間波 及分析, ジャレフ・ジャーナル（不動産ファイナンス・ 不動産経済学研究), No. 5, pp. 23-39, 2011.

56) Seya, H., Tsutsumi, M. and Yamagata, Y.: Income convergence in Japan: A Bayesian spatial Durbin model approach, Economic Modelling, Vol. 29, No. 1, pp. 60-71, 2012.

57) Gerkman, L. : Empirical spatial econometric modeling of small scale neighbourhood, Journal of Geographical Systems, Vol. 14, No. 3, pp. 283-298, 2012.

58) Anselin L. : Under the food: Issues in the specification and interpretation of spatial regression models, Agricultural Economics, Vol. 27, No. 3, pp. 247-267, 2002.

59) Stakhovych, S. and Bijmolt, T. H. A. : Specification of spatial models: A simulation study on weights matrices, Papers in Regional Science, Vol. 88, No. 2, pp. 389-408, 2008.

60) 渡辺理, 樋口洋一郎：ネットワーク自己相関分析：モ バイル IT システム利用行動における連携利用パター ンの把握と活用に関する考察, 情報処理学会論文誌, Vol. 46, No. 5, pp. 1222-1232, 2005.

61) Corrado, L. and Fingleton, B. : Where is the economics in spatial econometrics?, Journal of Regional Science, Vol. 52,
No. 2, pp. 210-239, 2012.

62) Getis, A. and Aldstadt, J. : Constructing the spatial weights matrix using a local statistic, Geographical Analysis, Vol. 36, No. 2, pp. 90-104, 2004.

63) Fernandez-Vazquez, E., Mayor-Fernandez, M. and Rodriguez-Valez, J. : Estimating spatial autoregressive models by GME-GCE techniques, International Regional Science Review, Vol. 32, No. 2, pp. 148-172, 2009.

64) Tiefelsdorf, M. and Griffith, D. : Semiparametric filtering of spatial auto-correlation: The eigenvector approach, Environment and Planning A, Vol. 39, No. 5, pp. 1193-1221, 2007.

65) Griffith, D. A. : Spatial Autocorrelation and Spatial Filtering: Gaining Understanding through Theory and Scientific Visualization, Berlin, Springer-Verlag, 2003.

66) Griffith, D. A. and Paelinck, J. H. P. : Non-standard Spatial Statistics and Spatial Econometrics, Berlin, Springer-Verlag, 2010.

67) Cressie, N. A. C. and Huang, H. C. : Classes of nonseparable, spatio-temporal stationary covariance functions, Journal of the American Statistical Association, Vol. 94, No. 448, pp. 1330-1340, 1999.

68）井上亮, 清水英範, 吉田雄太郎, 李勇鶴 : 時空間クリ ギングによる東京 23 区・全用途地域を対象とした公 示地価の分布と変遷の視覚化, GIS - 理論と応用, Vol. 17, No. 1, pp. 13-24, 2009.

69) Stroud, J. R., Müller, P. and Sansó, B. : Dynamic models for spatiotemporal data, Journal of the Royal Statistical Society: Series B, Vol. 63, No. 4, pp. 673-689, 2001.

70) Stroud, J. R., Stein, M. L., Lesht, B. M., Schwab, D. J. and Beletsky, D. : An ensemble Kalman filter and smoother for satellite data assimilation, Journal of the American Statistical Association, Vol. 105, No. 491, pp. 978-990, 2010.

71) Anselin, L., Le Gallo, J. and Jayet, H. : Spatial panel econometrics, The Econometrics of Panel Data, Fundamentals and Recent Developments in Theory and Practice, 3rd Edition (eds. Matyas, L., and Sevestre, P.), pp. 627-662, Dordrecht, Kluwer, 2008.

72) 北村行伸：パネルデータ分析, 岩波書店, 2005 .

73) Elhorst, J. P. : Specification and estimation of spatial panel data models, International, Regional Science Review, Vol. 26, No. 3, pp. 244-268, 2003.

74) Kapoor, M., Kelejian, H. H. and Prucha, I. R. : Panel data models with spatially correlated error components, Journal of Econometrics, Vol. 140, No. 1, pp. 97-130, 2007.

75) Lee, L. F. and Yu, J. : Some recent developments in spatial panel data models, Regional Science and Urban Economics, Vol. 40, No. 5, pp. 255-271, 2010. 
76) Wall, M. M. : A close look at the spatial structure implied by the CAR and SAR models, Journal of Statistical Planning and Inference, Vol. 121, No. 2, pp. 311-324, 2004.

77) Kelejian, H. H. and Prucha, I. R. : HAC estimation in a spatial framework, Journal of Econometrics, Vol. 140, No. 1, pp. 131-154, 2007.

78) Folmer, H. and Oud, J. : How to get rid of W: A latent variables approach to modelling spatially lagged variables, Environment and Planning A, Vol. 40, No. 10, pp. 2526-2538, 2008.

79) Seya, H., Yamagata, Y. and Tsutsumi, M. : Automatic selection of a spatial weight matrix in spatial econometrics: Application to a Spatial Hedonic Approach, presented at the AsRES \& AREUEA joint international conference, Singapore, July 7-10, 2012.

80) Sampson, P. D. and Guttorp, P. : Nonparametric estimation of nonstationary spatial covariance structure, Journal of the American Statistical Association, Vol. 87, No. 417, pp. 108-119, 1992.

81) Higdon, D. M., Swall, J. and Kern, J. : Non-stationary spatial modeling, Bayesian Statistics 6 (eds. Bernardo, J. M., Berger, J. O., David, A. P. and Smith, A. F. M), pp. 761-768, Oxford, Oxford University Press, 1999.

82) Darbeheshti, N. and Featherstone, W. E. : Non-stationary covariance function modelling in $2 \mathrm{D}$ least-squares collocation, Journal of Geodesy, Vol. 83, No. 6, pp. 495-508, 2009.

83 ) 堤盛人, 清水英範, 井出裕史 : 誤差要素モデルに基づ く Kriging を用いた空間内挿, 応用力学論文集, Vol. 3, pp. 125-132, 2000.

84) Fischer, M. M. and Getis, A. : Handbook of Applied Spatial Analysis: Software Tools, Methods and Applications, Berlin, Springer-Verlag, 2010.

85) Bivand, R. : Implementing spatial data analysis software tools in R, Geographical Analysis, Vol. 38, No. 1, pp. 23-40, 2006.

86) Bivand, R. S., Pebesma, E. J. and Gómez-Rubio, V. : Applied Spatial Data Analysis with R, New York, Springer, 2008.

87) Remy, N., Boucher, A. and Wu, J. : Applied Geostatistics with SGeMS, Cambridge, Cambridge University Press, 2009.

88) Pebesma, E. : Spatio-temporal geostatistics using gstat, 2012 (http://cran.r-project.org/web/packages/gstat/vignette s/st.pdf).

89) Hengl, T. : A practical guide to geostatistical mapping of environmental variables, Scientific and Technical Research Series, EUR 22904 EN, Luxembourg: Office for Official
Publications of the European Communities, 2007.

90) Bivand, R. : Spatial econometrics functions in R: Classes and methods, Journal of Geographical Systems, Vol. 4, No. 4, pp. 405-421, 2002.

91) Piras, G. : sphet: Spatial models with heteroskedastic innovations in R, Journal of Statistical Software, Vol. 35, No. 1, 2010.

92) Drukker, D. M., Prucha, I. R. and Raciborski, R. : A command for estimating spatial-autoregressive models with spatial-autoregressive disturbances and additional endogenous variables, The Stata Journal, Vol. 1, No. 1, pp. 1-13, 2001.

93) Rey, S. J. and Anselin, L. : PySAL: A Python library of spatial analytical methods, The Review of Regional Studies, Vol. 37, No. 1, pp. 5-27, 2007.

94) Elhorst, J. P. : MATLAB software for spatial panels, 2011, Available at http://www.regroningen.nl/elhorst/doc/Matlabpaper.pdf

95) Pinkse, J., Slade, M. E. and Brett, C. : Spatial price competition: A semiparametric approach, Econometrica, Vol. 70, No. 3, pp. 1111-1153, 2002.

96) Maddison, D. : Environmental Kuznets curves: A spatial econometric approach, Journal of Environmental Economics and Management, Vol. 51, No. 2, pp. 218-230, 2006.

97) Rey, S. J. : Integrated regional econometric + input-output modeling: Issues and opportunities, Papers in Regional Science, Vol. 79, No. 3, pp. 271-292, 2000.

98) Brueckner, J. K. : Testing for strategic interaction among local governments: The case of growth controls, Journal of Urban Economics, Vol. 44, No. 3, pp. 438-467, 1998.

99) Bradlow, E., Bronnenberg, B., Russell, G., Arora, N., Bell, D., Duvvuri, S., Hofstede, F., Sismeiro, C., Thomadsen, R. and Yang, S.: Spatial models in marketing, Marketing Letters, Vol. 16, No. 3, pp. 267-678, 2005.

100) Manski, C. F. : Identification of endogenous social effects: The reflection problem, The Review of Economic Studies, Vol. 60, No. 3, pp. 531-542, 1993.

101) Gibbons, S. and Overman, H. G. : Mostly pointless spatial econometrics?, Journal of Regional Science, Vol. 52, No. 2 , pp. 172-191, 2012.

102) Can, A. : The measurement of neighborhood dynamics in urban house prices, Economic Geography, Vol. 66, No. 3, pp. 254-272, 1990.

103) 高塚創，樋口洋一郎：空間的自己相関分析手法を用い た地価の空間的連関に関する統計的検証, 地域学研 究, Vol. 26, No. 1, pp. 139-153, 1996.

104) 堤盛人, 清水英範, 福本潤也, 井出裕史 : 誤差項に空 間的自己相関が存在する回帰モデルのパラメータ推 
定法に関する考察, 土木計画学研究・論文集, Vol. 15, pp. 49-56, 1998.

105) Kim, C. W., Phipps, T. T. and Anselin, L. : Measuring the benefits of air quality improvement: A spatial hedonic approach, Journal of Environmental Economics and Management, Vol. 45, No. 1, pp. 24-39, 2003.

106) Anselin, L. and Le Gallo, J. : Interpolation of air quality measures in hedonic house price models: Spatial aspects, Spatial Economic Analysis, Vol. 1, No. 1, pp. 31-52, 2006.

107) Anselin, L. and Lozano-Gracia, N. : Errors in variables and spatial effects in hedonic house price models of ambient air quality, Empirical Economics, Vol. 34, No. 1, pp. 5-34, 2008.

108) Cho, S-H., Lambert, D. M., Kim, S. G., Roberts, R. K. and Park, W. M. : Relationship between value of open space and distance from housing locations within a community, Journal of Geographical Systems, Vol. 13, No. 4, pp. 393-414, 2011.

109) Gelfand, A. E., Ecker, M. D., Knight, J. R. and Sirmans, C. F. : The dynamics of location in home price, Journal of Real Estate and Financial Economics, Vol. 29, No. 2, pp. 149-166, 2004.

110) Valente, J. Wu., S., Gelfand, A. and Sirmans, C. F. : Apartment rent prediction using spatial modeling, Journal of Real Estate Research, Vo. 27, No. 1, pp. 105-136, 2005.

111) 堤盛人, 吉田靖, 瀬谷創, 川口有一郎：MCMC 法によ るデータ欠損問題と空間的相関を考慮した不動産賃 料予測モデル：東京 23 区における賃貸マンション市 場の実証分析，ジャレフ・ジャーナル（不動産ファイ ナンス・不動産経済学研究), Vol. 3, pp. 1-13, 2008.

112) Anselin, L. and Lozano-Gracia, N. : Spatial hedonic models, Palgrave Handbook of Econometrics Volume 2: Applied Econometrics, (eds. Mills, T. C., and Patterson, K.), pp. 1213-1250, Basingstoke, Palgrave Macmillan, 2009.

113) Small, K. A. and Steimetz, S. S. C. : Spatial hedonics and the willingness to pay for residential amenities, Journal of Regional Science, in print, 2012.

114)堤盛人, 瀬谷創：便益計測への空間へドニック・アプ ローチの適用, 土木学会論文集 D, Vol. 66, No. 2, pp. 178-196, 2010.

115) Zietz, J., Zietz, E. N. and Sirmans, G. S. : Determinant of housing prices: a quantile regression approach, Journal of Real Estate Finance and Economics, Vol. 37, No. 4, pp. 317-333, 2008.

116) Zhu, B., Füss, R. and Rottke, N. B. : The predictive power of anisotropic spatial correlation modeling in housing prices, Journal of Real Estate Finance and Economics, Vol. 42, No. 4, pp. 542-565, 2011.
117) Jeanty, P. W., Partridge, M. and Irwin, E. : Estimation of a spatial simultaneous equation model of population migration and housing price dynamics, Regional Science and Urban Economics, Vol. 40, No. 5, pp. 343-352, 2010.

118) Seya, H. and Tsutsumi, M. : Spatial hierarchal Bayesian model for missing data imputation, presented at the Fourth World Conference of the Spatial Econometrics Association, Courtyard Magnificent Mile Downtown Chicago Hotel, Chicago, Illinois, USA, 9-12, 2010.

119)植杉大：時空間的相関を考慮した小地域不動産価格イ ンデックスのベイズ MCMC 推定, 摂南経済研究, Vol. 1, No. 1-2, pp. 39-51, 2011.

120) Banerjee, S., Gelfand, A. E., Knight, J. R. and Sirmans, C. F. : Weighted sum of stationary process, Journal of Business and Economic Statistics, Vol. 22, No. 2, pp. 206-213, 2004b.

121) Fernandez, V. : Spatial linkages in international financial markets, Quantitative Finance, Vol. 11, No. 2, pp. 237-245, 2011.

122) 中村良平 : ヘドニック・アプローチにおける実証分析 の諸問題, 土木学会論文集, Vo. 449/IV-17, pp. 57-66, 1992.

123) Geniaux, G. and Napoléone, C. : Semi-parametric tools for spatial hedonic models: An introduction to mixed geographically weighted regression and geoadditive models, Hedonic Methods in Housing Markets (eds. Baranzini, A., Ramirez, J., Schaerer, C., and Thalmann, P. ), pp. 101-128, Berlin, Springer-Verlag, 2008.

124) 瀬谷創, 堤盛人, 吉田靖, 川口有一郎 : 空間的自己相 関を考慮した不動産賃料の空間予測モデルに関する 実証比較分析, ジャレフ・ジャーナル（不動産ファイ ナンス・不動産経済学研究), No. 5, pp. 1-21, 2011.

125) Kammann, E. E. and Wand, M. P. : Geoadditive models, Journal of the Royal Statistical Society: Series C, Vol. 52, No. 1, pp. 1-18, 2003.

126) McMillen, D. P. : Issues in spatial data analysis, Journal of Regional Science, Vol. 50, No. 1, pp. 119-141, 2010.

127) Baltagi, B. H. and Li, D. : Testing for linear and log-linear models against Box-Cox alternatives with spatial lag dependence, Advances in Econometrics, Volume 18: Spatial and Spatiotemporal Econometrics (eds. LeSage, J. P. and Pace, R. K. ), pp. 35-74, Elsevier Science, Oxford, 2004.

128) Gelfand, A. E., Banerjee, S., Sirmans, C. F., Tu, Y. and Ong., S. E.: Multilevel modeling using spatial processes: Application to the Singapore housing market, Computational Statistics \& Data Analysis, Vol. 51, No. 7, pp. 3567-3579, 2007.

129) 山形与志樹, 村上大輔, 瀬谷創, 堤盛人：環境 - 災害 
リスク指標とマンション価格のマルチレベルモデル による空間計量経済分析，土木計画学研究・講演集，

Vol. 43, CD-ROM, 2011

130) Pace, R. K., Barry, R., Clapp, J. M. and Rodriquez, M. : Spatiotemporal autoregressive models of neighborhood effects, The Journal of Real Estate Finance and Economics, Vol. 17, No. 1, pp. 15-33, 1998.

131) Sun, A., Tu, Y. and Yu, S-M. : A spatio-temporal autoregressive models for multi-unit residential market analysis, The Journal of Real Estate Finance and Economics, Vol. 31, No. 2, pp. 155-187, 2005.

132) Nappi-Choulet, I. and Maury, T. : A spatiotemporal autoregressive price index for the Paris office property market, Real Estate Economics, Vol. 37, No. 2, pp. 305-340, 2009.

133) Beamonte, A., Gargallo, P. and Salvador, M. : Analysis of housing price by means of STAR models with neighborhood effects: A Bayesian approach, Journal of Geographical Systems, Vol. 12, No. 2, pp. 227-240, 2010.

134) Pace, R. K., Barry, R. and Sirmans, C. F. : Spatial statistics and real estate, Journal of Real Estate Finance and Economics, Vol. 17, No. 1, pp. 5-13, 1998.

135) Fingleton, B. and López-Bazo, E. : Empirical growth models with spatial effects, Papers in Regional Science, Vol. 85, No. 2, pp. 177-198, 2006.

136) 江尻良, 奥村誠, 小林潔司：社会資本の生産性と経済 成長: 研究展望, 土木学会論文集, No. 688/IV-53, pp. 75-87, 2001.

137) Rey, S. J. and Montouri, B. D. : US regional income convergence: A spatial econometrics perspective, Regional Studies, Vol. 33, No. 2, pp. 143-156, 1999.

138) Rey, S. J. and Dev, B. : $\sigma$-convergence in the presence of spatial effects, Papers in Regional Science, Vol. 85, No. 2, pp. 217-234, 2006.

139) Abreu, M., de Groot, H. L. F. and Florax, R. J. G. M. : Space and growth: A survey of empirical evidence and methods, Région et Développement, Vol. 21, pp. 12-43, 2004.

140) López-Bazo, E., Vayá, E. and Artís, M. : Regional externalities and growth: Evidence from European regions, Journal of Regional Science, Vol. 44, No. 1, pp. 43-73, 2004.

141) Vayá, E., López-Bazo, E., Moreno, R. and Surinach, J. : Growth and externalities across economies: An empirical analysis using spatial econometrics, Advances in Spatial Econometrics: Methodology, Tools and Applications (eds. Anselin, L., Florax, R. J. G. M., and Rey, S. J. ), pp. 433-455, Berlin, Springer-Verlag, 2004.

142) Pfaffermayr, M. : Conditional $\beta$ - and $\sigma$-convergence in space: A maximum likelihood approach, Regional Science and Urban Economics, Vol. 39, No. 1, pp. 63-78, 2009.

143) Egger, P. and Pfaffermayr, M. : Spatial convergence, Papers in Regional Science, Vol. 85, No. 2, pp. 199-215, 2006.

144) Ertur, C. and Koch, W.: Growth, technological interdependence and spatial externalities: Theory and evidence, Journal of Applied Econometrics, Vol. 22, No. 6, pp. 1023-1062, 2007.

145) Fischer, M. M. : A spatial Mankiw-Romer-Weil model: theory and evidence, The Annals of Regional Science, Vol. 47, No. 2, pp. 419-436, 2011.

146) 中村良平：都市・地域における経済集積の測度（上）, 岡山大学経済学会雑誌, Vol. 39, No. 4, pp. 99-121, 2008.

147) Cliff, A. and Ord, J. K. : Spatial Processes: Methods and Applications, London, Pion, 1981.

148) Arbia, G. : The role of spatial effects in the empirical analysis of regional concentration, Journal of Geographical Systems, Vol. 3, No. 3, pp. 271-281, 2001.

149) Moran, P. A. : A test for the serial dependence of residuals, Biometrika, Vol. 37, pp. 178-181, 1950.

150) Getis, A. and Ord, J. K. : The analysis of spatial association by use of distance statistics, Geographical Analysis, Vol. 24, No. 3, pp. 189-199, 1992.

151) Rey, S. J. and Janikas, M. V. : STARS: Space-time analysis of regional systems, Geographical Analysis, Vol. 38, No. 1, pp. 67-84, 2006.

152) Kelejian, H. H. and Mukerji, P. : Important dynamic indices in spatial models, Papers in Regional Science, in print, 2011.

153) Guillain, R. and Le Gallo, J. : Agglomeration and dispersion of economic activities in and around Paris: an exploratory spatial data analysis, Environment and Planning B, Vol. 37, No. 6, pp. 961-981, 2010.

154) Anselin, L. : Local indicators of spatial association-LISA, Geographical Analysis, Vol. 27, No. 2, pp. 93-115, 1995.

155) Rusche, K., Kies, U. and Schulte, A. : Measuring spatial co-agglomeration patterns by extending ESDA techniques, Jahrbuch für Regionalwissenschaft, Vol. 31, No. 1, pp. $11-25,2011$.

156) Arbia, G., Espa, G., Giuliani, D. and Mazzitelli, A. : Detecting the existence of space-time clustering of firms, Regional Science and Urban Economics, Vol. 40, No. 5, pp. $311-323,2010$

157) Kosfeld, R., Eckey, H-F. and Lauridsen, J. : Spatial point pattern analysis and industry concentration, The Annals of Regional Science, Vol. 47, No. 2, pp. 311-328, 2011.

158) Marcon, E. and Puech, F. : Measures of the geographic 
concentration of industries: Improving distance-based methods, Journal of Economic Geography, Vol. 10, No. 5, pp. 745-762, 2010.

159) 村上大輔, 山形与志樹, 瀬谷創, 堤盛人：空間統計手 法による東京都市圈の業務集積地の抽出, 応用地域学 会第 25 回 富山大会, 2011 年 12 月 2,3 日.

160) 村上大輔, 山形与志樹, 瀬谷創, 堤盛人 : 東京都市圈 における業務交通トリップの空間構造の分析とマッ ピング, 土木計画学研究・講演集 46 (発表予定).

161) Ord, J. K. and Getis, A. : Local spatial autocorrelation Statistics: Distributional issues and an application, Geographical Analysis, Vol. 27, No. 4, pp. 286-306, 1995.

162) Rogerson, P. A. : The Detection of clusters using a spatial version of the chi-square goodness-of-fit statistic, Geographical Analysis, Vol. 31, No. 2, pp. 130-147, 1999.

163) Peeta, S. and Ziliaskopoulos, A. K. : Foundations of dynamic traffic assignment: The past, the present and the future, Networks and Spatial Economics, Vol. 1, No. 3-4, pp. 233-265, 2001.

164) Hackney, J. K., Bernard, M., Bindra, S. and Axhausen, K. W. : Predicting road system speeds using spatial structure variables and network characteristics, Journal of Geographical Systems, Vol. 9, No. 4, pp. 397-417, 2007.

165) Kamarianakis, Y. and Prastacos, P. : Forecasting traffic flow conditions in an urban network: Comparison of multivariate and univariate approaches, Transportation Research Record-Journal of the Transportation Research Board, No. 1857, pp. 74-84, 2003.

166) Wang, X. and Kockelman, K. : Forecasting network data: Spatial interpolation of traffic counts using Texas data, Transportation Research Record, No. 2105, pp. 100-108, 2009.

167) Miura, H. : A study of travel time prediction using universal kriging, Top, Vol. 18, No. 1, pp. 257-270, 2010.

168) Schuessler, N. and Axhausen, K. W. : Recent developments regarding similarities in transport modeling, presented at the 7th Swiss Transport Research Conference, 2007, http://e-col lection.library.ethz.ch/eserv/eth:30231/eth-30231-01.pdf

169) Mohammadian, A. K., Haider, M. and Kanaroglou, P. S. : Incorporating spatial dependencies in random parameter discrete choice models, presented at the 84th Annual Meeting of the Transportation Research Board, Washington, D. C., January 2005.

170) Robertson, R. D., Nelson, G. C. and De Pinto, A. : Investigating the predictive capabilities of discrete choice models in the presence of spatial effects, Papers in Regional Science, Vol. 88, No. 2, pp. 327-344, 2009.

171) Miyamoto, K., Vichiensan, V., Shimomura, N. and Paez, A. :
Discrete choice model with structuralized spatial effects for location analysis, Transportation Research Record, Journal of the Transportation Research Board, Vol. 1898, pp. 183-190, 2004.

172) Smirnov, O. A. and Egan, K. J. : Spatial random utility model with an application to recreation demand, Economic Modelling, in print, 2011.

173) Klier, T. and McMillen, D. P. : Clustering of auto supplier plants in the U. S. : GMM spatial logit for large samples, Journal of Business and Economic Statistics, Vol. 26, No. 4, pp. 15-38, 2008.

174) 屋井鉄雄, 中川隆広 : 構造化プロビットモデルの発展 性, 土木計画学研究·論文集, Vol. 13, pp. 563-570, 1993.

175) Chakir, R. and Parent, O. : Determinants of land use changes: A spatial multinomial probit approach, Papers in Regional Science, Vol. 88, No. 2, pp. 327-344, 2009.

176) Griffith, D. A. : Spatial structure and spatial interaction: 25 years later, The Review of Regional Studies, Vol. 37, No. 1, pp. 28-38, 2007.

177) Curry, L. : A spatial analysis of gravity flows, Regional Studies, Vol. 6, No. 2, pp. 137-147, 1972.

178) Griffith, D. A. and Jones, K. G. : Explorations into the relationship between spatial structure and spatial interaction, Environment and Planning A, Vol. 12, No. 2, pp. 187-201, 1980.

179) LeSage, J. P. and Pace, R. K. : Spatial econometric modeling of origin-destination flows, Journal of Regional Science, Vol. 48, No. 5, pp. 941-967, 2008.

180) Tsutsumi, M. and Tamesue, K. : Intraregional flow problem in spatial econometric model for origin-destination flows, Environment and Planning $B$, forthcoming.

181)古谷知之：ベイズ地理的加重回帰モデルの地価モデル 推定への適用, 都市計画論文集, Vol. 39, No. 3, pp. 787-792, 2004.

182) Huang, B., Wu, B., and Barry, M. : Geographically and temporally weighted regression for modeling, spatio-temporal variation in house prices, International Journal of Geographical Information Science, Vol. 24, No. 3, pp. 383-401, 2010.

183) Mennis, J. : Mapping the results of geographically weighted regression, The Cartographic Journal, Vol. 43, No. 2, pp. 171-179, 2006.

184) Tsutsumi, M., Shimada, A. and Murakami, D. : Land price maps of Tokyo metropolitan area, Procedia Social and Behavioral Sciences, Vol. 21, pp. 193-202, 2011.

185) Tsutsumi, M. and Seya, H. : Measuring the impact of large-scale transportation project on land price using spatial 
statistical models, Paper in Regional Science, Vol. 87, No. 3, pp. 385-401, 2008.

186) Páez, A. , 内田敬, 宮本和明：Urbanization and the urban heat island effect from a spatial descriptive approach，都市 計画論文集, Vol. 33, pp.67-72, 1998.

187) Alesheikh, A. A. and Omidvari, M. : Application of GIS in urban traffic noise pollution, International Journal of Occupational Hygiene, Vol. 2, No. 2, pp. 87-92, 2011.

188) Kerry, R., Goovaerts, P., Haining, R. P. and Ceccato, V. : Applying geostatistical analysis to crime data: Car-related thefts in the Baltic States, Geographical Analysis, Vol. 42, No. 1, pp. 53-77, 2010.

189) Cressie, N. A. C. and Johannesson, G. : Fixed rank kriging for very large spatial data sets, Journal of the Royal Statistical Society B, Vol. 70, No. 1, pp. 209-226, 2008.

190) Hall, D. L. : Mathematical Techniques in Multisensor Data Fusion, Artech House, Inc., Norwood, MA, USA, 2004.

191) Nguyen, H. : Spatial statistical data fusion for remote sensing applications, UCLA Statistics Dissertations, 2009. http://the ses.stat.ucla.edu/abstract.php?dissertation $=104$

192) Atkinson, P. M. and Lloyd, C. D. : Non-stationary variogram models for geostatistical sampling optimisation: An empirical investigation using elevation data, Computers \& Geosciences, Vol. 33, No. 10, pp. 1285-1300, 2007.

193) Hernández, J. and Emery, X. : A geostatistical approach to optimize sampling designs for local forest inventories, Canadian Journal of Forest Research, Vol. 39, No. 8, pp. 1465-1474, 2009.

194) Gotway, C. A. and Young, L. J. : Combining incompatible spatial data, Journal of the American Statistical Association, Vol. 97, No. 458, pp. 632-648, 2002.

195) Sadahiro, Y. : Accuracy of areal interpolation: A comparison of alternative methods, Journal of Geographical Systems, Vol. 1, No. 4, pp. 323-346, 1999.

196) Kyriakidis, P. C. : A geostatistical framework for area-to-point spatial interpolation, Geographical Analysis, Vol. 36, No. 3, pp. 259-289, 2004.

197) Wikle, C. K. and Berliner, L. M. : Combining information across spatial scales, Technometrics, Vol. 47, No. 1, pp. 80-91, 2005.

198) Yoo, E. -H., Kyriakidis, P. C. and Tobler, W. : Reconstructing population density surfaces from areal data: A comparison of Tobler's pycnophylactic interpolation method and area-to-point kriging, Geographical Analysis, Vol. 42, No. 1, pp. 78-98, 2010.

199)村上大輔, 堤盛人:Kriging を用いた実用的な面補間法, GIS-理論と応用, Vol. 19, No. 2, pp. 59-69, 2011.

200) Polasek, W. and Sellner, R. : Spatial Chow-Lin methods for data completion in econometric flow models, Institute for Advanced Studies in its series Economics Series with number 255, 2010.

201)堤盛人, 村上大輔：市町村合併による統計データの集 計単位変更に対する空間計量経済モデルを用いた面 補間法, 応用地域学研究, Vol. 15, pp. 23-35, 2010.

202) 柏谷増男: 土木計画学研究 30 年の成果と展望, 第 30 回土木計画学シンポジウム 新しい国づくり・街づく りをめざして (土木学会 土木計画学研究委員会編), pp. 31-38, 土木学会, 1996.

203) 堤盛人：一般均衡理論による計測便益の統計的性質, 森杉壽芳編著：社会資本整備の便益評価-一般均衡理 論によるアプローチ, pp.63-70, 勁草書房, 1997.

(2012. 9. 28 受付)

\section{PERSPECTIVE ON APPLIED SPATIAL STATISTICS: FOCUSING ON THE APPLICATION TO INFRASTRUCTURE PLANNING}

\section{Morito TSUTSUMI and Hajime SEYA}

Applied spatial statistics mainly involves the application of spatial statistical and spatial econometric techniques, and it is an excellent tool for modeling geospatial data. Spatial statistics, which includes elements of geostatistics, originated from mining engineering, and spatial econometrics originated from regional science. The recent advancements in the field of geographic information systems (GIS) have provided researchers and practitioners access to detailed spatial datasets and have allowed them to apply the abovementioned techniques to socioeconomic data. However, to the best of our knowledge, there are no significant reviews on the empirical application of these techniques. Hence, the purpose of this study was to review literatures on the empirical application, especially in infrastructure planning. This paper also discusses the future direction of applied spatial statistics in detail. 